\title{
Are Countries Participating into Regional Integration Performing Better in Growth and Liberalization Than Non-Participators? A Study on European Countries
}

\author{
Tarun Kanti Bose ${ }^{1} \&$ Jannatul Ferdous Bristy ${ }^{2}$ \\ ${ }^{1}$ Business Administration Discipline, Khulna University, Bangladesh \\ ${ }^{2}$ Human Resource Management Discipline, Khulna University, Bangladesh \\ Correspondence: Tarun Kanti Bose, Business Administration Discipline, Khulna University, Bangladesh. E-mail: \\ tarun84ku@yahoo.com
}

Received: October 23, 2016

Accepted: January 20, 2017

Online Published: January 26, 2017

doi:10.5539/ijbm.v12n2p171

URL: http://dx.doi.org/10.5539/ijbm.v12n2p171

\begin{abstract}
This study conducted towards identifying practical scenario of effectiveness of regional integration on indicators of trade liberalization and economic growth. Empirical analysis using secondary yet quantitative data using eight ratio and trend analysis on 49 European countries (28 EU and 21 Non-EU) portrays outcome in favor of regional integration. While EU countries seem to be performing consistently in both the categories, Non-EU countries are lagging behind. This outcome comes in the support of the traditional supports of free trade and integration and declares that trade integration creates both dynamic and static effects and trades (open and participatory) actually benefit all.
\end{abstract}

Keywords: regional integration, trade liberalization, economic growth, EU, Non-EU

\section{Introduction}

Reading theories of international trade is probably one of the most pleasant things to do for us as it is certainly interesting and simultaneously presents scopes for debate and vale addition in virtually every line. Theorists and scientist of international trade over the years strive hard to produce universal theories and yet most of the time theories became regional and only been able to gain local context. Some says this is the beauty of this field as it is always try to make an affair with the black box. Making affair with the known is easy and presents no real winning pleasure but making bondages with black boxes is totally opposite. Black boxes in international trade are common and will be there till eternity. The reason behind is old and traditional and like a philosopher we can say every individual is different, no country is similar, no society is unique and vice versa. The foregone conclusion is international trade is diversified and participators and players are no different. Gaining supremacy in such fiery and bloody playground is not easy by any means and counter toughness and robustness is essential. Now the key underlying question is how to gain such supremacy? Well a lot of answers available in the books of international business and entrepreneurship also in the basic books of business management. Innovation, cost effectiveness, CSAs (Country Specific Advantages) FSAs (Firm Specific Advantages) development, technology initiator, change agent, price leadership, organizational harmony and synergy and a never ending list. One thing sometimes missed in the list is doing it jointly not in terms of organizations but for countries. This means countries should come together regionally for performing better internationally. How such joint operation and common platform which termed commonly in literature as regional integration helps? There are numerous researches across the planet to find out the exact answer. How it helps? Does it really help? How far it can go? Up to what to what extent the benefits can reach their level? All of the stakeholders of the research and theories of international trade and economic development cared about these issues and always sacrifice their precious time and effort to find out the answer. This study is no exception.

Over the years there have been a lot of studies carried out for detecting the impact of regional integration on economic performance of countries of various parts of the world. It is evident from those studies that regional integration among countries creates economic benefits. Participations in regional integration creates different sorts of static and dynamic effects thus economies obtained significant benefit. Common market, common currencies, relaxing trade barriers are different forms of regional integration benefitting different countries across 
the world in Africa, Asia, Europe and also in North America. Countries of different economic, social and population statures benefits from such integration. Say for example the case of NAFTA-the regional integration among Mexico, the US and Canada. It was obvious that a country like Mexico which is a relatively poor economy with larger population benefitting from FDI of US and Canadian companies. On the other hand Canadian and US' companies are also getting benefits from cheap labor force of Mexico which they may have been produced in other parts of the world like India, China or in Europe. They are also getting benefits of such integration. Therefore there is not even slimmest doubt that integration helps. But-up to what extent? Is the benefit is equally distributed among all the countries? What about neighboring countries which are not part of such integration? Is integration making economies more liberal? Vibrant and comprehensive answers of these important related questions are still seem to be unanswered. The real value of this study existed in that area.

In a comprehensive attempt to mitigate the above key issues of research works in the field of regional integration we have carried out this study. More importantly it has been conducted on Europe. Europe the most advanced continent of the world and EU certainly the most structured and diversified integration took place ever. Therefore, there cannot be any better group of countries to carry out such studies. In addition, there are also many countries in Europe which are not part of EU. Therefore, as neighboring nations how they are performing is critical to investigate. We have done all those things and by doing so we have answered many unanswered and untouched questions and contribute in the existing literatures. First of all we have analyzed the data last 43 years for EU countries. Such data analysis has been done for two phases: before integration and after integration. First phase was between 1970-1993 and later stage was between 1994-2013. In order to detect both liberalization and growth we have used eight trends and ratio analysis. Those indicators have been calculated for both the periods of before and after and the impact of integration has been evaluated. In next phase we have done the similar analysis on Non-EU countries for detecting their performance in both the indicators. By doing that we have uncovered following important phenomenon: How EU countries were performing in term of growth and liberalization before integration? How they are performing after integration? How Non-EU countries are performing in the entire period? What is the comparative performance of EU and Non-EU countries? By interpreting those issues many new areas in these field of research has been explored including detection of comprehensive impact of static and dynamic effect and also negative impact of such effects on non members countries. This value addition is done along with traditional contributions of answering traditional research questions.

\section{Literature Review}

\subsection{Economic Integration}

Integration generally means to combine something together. Integration can be viewed from two perspectives: economic and socio-political (Naveh et al. 2012). When integration involves the assimilation of different economies by carrying out policies to create mutual economic interdependence, it is called economic integration (Mutharika, 1972). Economic integration aims at developing ties between or among countries by fully removing the restrictions on trade, labor, capital and other resources movements (Robson, 1987 and Carbaugh, 2004). It also calls for the lack of any sort of discrimination and trade impediments, ongoing abolition of economic frontiers, co-operation and co-ordination of economic policies or even exchange rates (Molle, 1990; El-Agraa, 1994 and Pelkmans, 2006). In generic terms, economic integration doesn't require geographically close countries to integrate together but to reduce trade costs and increase welfare. Again, it is not a static idea; rather it is an evolving and changing process (Snorrason, 2012).

\subsection{Regional Economic Integration}

A very much related concept that is often used interchangeably with economic integration is regional economic integration (Mutharika, 1972 and Winter, 1996). If these two concepts are viewed differently, then regional economic integration is a series of policies that establish joint institutional mechanisms, remove or reduce the discrimination between local and foreign goods, services and factors (Salvatore,1997) and causes the economic and financial convergence of the integrating countries (Venables, 1999). These countries are geographically situated in proximity to one another. In other sense, regional economic integration is the reduction and ultimate removal of tariff and non-tariff barriers and the agreement among neighboring countries to coordinate their trade, fiscal and monetary policies (Narendra and Goel, 2014). Regional economic integration can be classified in five types: free trade area, customs union, common market, economic union and political union.

\subsection{Advantages of Economic Integration}

Regional economic integration allows member countries to specialize in the production of products that they can produce with greater competitive advantages and import others facing little or no restriction. Therefore, it is not 
required to produce every product in every country to avoid trade cost. It increases the efficiency in production (Krugman 1991 and Lyakurwa, 1997) and the economic activities are concentrated (Baldwin, 1997). Efficiency also increases for intensified competition as domestic firms are to compete with other producers of member countries because foreign investment is increased. Competition is always good for market. Increased competition due to economic integration not only benefits the producers but also the benefits accrued to the producers are passed to the consumers too. Competition driven efficiency causes better production, consumers have augmented consumption, business profits increases, producers hire more workers and real income rises for all which leads to greater welfare, overall growth and development (Narendra and Goel, 2014). As countries can enter into larger market due to integration, they can increase their production, which results in economies of scale (Lipsey, 1987). Not only the volume of production but also the amount, quality and mobility of factors of production are improved because of technological and other advantages. Thus, regional integration also helps to save scarce national resources and distribute optimum income properly (Naveh et al. 2012). Economic integration also allows the member countries to act in a body coordinating their monetary and fiscal policies and taking collective position that increases international bargaining power (El-Agraa, 1994).

\subsection{Impacts of Economic Integration}

\subsubsection{Static Effects}

Static effects occur when resources are directed to locations where cheap and efficient production is possible. Static effects may happen due to either trade creation or trade diversion or both. When trade barriers among countries are removed or reduced by creating a regional trading bloc or integration agreements, members countries can easily enter to the areas of each other. They can now have a cheaper access to resources of member countries, can reduce production costs, sell products outside of their own territory and thus become more efficient. Trade diversion occurs when because of the existing barriers with non-member countries, foreign investment moves from those non-member countries to the countries within the regional trading bloc. Cline (1978) identified some other non-traditional static effects of regional trade integration: labor opportunity effect, economies of scale effect and foreign exchange saving effect. Baldwin and Venables (1995) and Lloyd and Maclaren (2004) pointed trade volume, trade cost and terms of trade as beneficial effects of regional trade integration assuming perfect competition and constant returns to scale. Besides, some other models assumed imperfect competition and increasing returns to scale and indentified output, scale and variety effects as static effects of regional economic integration (Negasi, 2009).

\subsubsection{Welfare Effects}

There is always a fierce debate over the actual advantages of regional economic integration. Few economists and trade analysts argued that regional agreements are corner stone of free trade and thus opens the door for trade and economic development. The counter arguments are not rare in this context and their claim is that regional agreements actually are discriminatory acts hence all the countries seldom receives equal treatment. In spite of the fact that these issues of regional agreements is vital for future economic integration and development, however a number of factors are preventing economists from reaching an unanimous decision on the effects of these agreements. Tariff liberalization under preferential trading arrangements makes it even more difficult o assesses the actual impact of trade integration on growth and trade liberalization. In addition the empirical scientific works also tend to be incapable in describing the dual impact of economic integration on growth and liberalization (Clausing, 2001 and Negasi, 2009).

\subsubsection{Dynamic Effects}

Dynamic effect resulted from efficiency changes, exploiting and taking advantages from economies of scale and also fostering the level of investment and economic growth (Hine, 1994 cited in Negasi, 2009). Three are different levels and types of dynamic effects which are both theoretically and empirically tested in the scientific literature of economics and international trade. First of all is the competition effect which occurs when imports are open across the partner countries of a certain regional agreement. Then there is also the existence of the investment effect which came along due to the practice and execution of the regional trade integration or agreement. More importantly these investments are only taking place due to agreement and would not been happened if there is no such regional integration. Next is the larger market spectrum resulted by economic integration. Larger markets open the chances to exploit the efficiency of economies of scale. Otherwise there would not been any chances to operate in larger scale and gain financially even more. Fourth and probably the most important effect is the capital formulation and more importantly larger capital access and which comes from various channels including: reduction on barriers to diffusion, technological transfer, externalities from export growth, rising marginal product of capital and soon. Fifth, the union members acting as a group may be 
more able to influence the terms of trade they face. Lastly, there is the structural transformation effect, which is a shift from traditional primary-products export to new industrial-products export. One significant advantage dynamic effects have over the static effects is its longer term impact even after the termination of the regional agreement. This simply means that even a country decide to withdraw itself from an regional forum it will still experience some sorts of positive influence of the dynamic effects which it has obtain due to the participation into the regional agreement (Negasi, 2009).

\subsection{Various Economic Integrations across the World}

\subsubsection{European Union (EU)}

$\mathrm{EU}$ is the most comprehensive example of regional economic integration that has been formed to remove the restriction on free movement of goods, services, people and capital among the member states. EU consists of twenty eight member states of Europe. The key institutions of the EU are: the European Commission, the Council of the European Union, the European Council, the Court of Justice of the European Union, the European Central Bank, the Court of Auditors, and the European Parliament. These institutions issue laws and policies, enact legislation and ensure the proper implementation of those. Eighteen countries within EU have a common currency-Euro, which was introduced in 1999 and fully enforced in 2002 (European Union, 2014).

\subsubsection{African Union (AU)}

Replacing the Organization of African Unity (OAU), African Union (AU) was established in 2001 in Addis Ababa but was launched in 2002 in South Africa. All other fifty four states of Africa excluding Morocco are AU's member states. Key decisions of AU are taken in the Assembly of the African Union (African Union, 2014).

\subsubsection{Union of South American Nations (USAN)}

USAN or UNASUR treaty was signed in 2008 to act as an intergovernmental union. As an ongoing process of South American integration, it has integrated two customs unions: MERCOSUR and the Andean Community of Nations (CAN). Following the EU model, it intends to have a common currency, parliament, and passport (Union of South American Nations, 2014).

\subsubsection{Caribbean Community (CARICOM)}

CARICOM was established in 1973 as an organization of 15 Caribbean nations and dependencies to promote economic integration and cooperation among its members and to ensure equitable benefits of integration for all. It also aims to coordinate foreign and economic policies and development planning. It also plans and organizes special projects for the less-developed countries within its jurisdiction, perform as a regional single market and to settle the disputes. It's headquarter is situated in Guyana (Caribbean Community Secretariat, 2014).

\subsubsection{Central American Integration System (SICA)}

Having its General Secretariat in El Salvador, SICA comprises of eight member states, three regional observers and four extra-regional observers. It was established in 1993 as an economic and political organization of Central American states to ensure the cooperation for regional peace, political freedom, democracy and economic development (Central American Integration System, 2014).

\subsubsection{Arab League (AL)}

Formed in Cairo during 1945 and currently having twenty two member states, AL is a regional organization of Arab countries to improve relationship and collaboration among member countries, to uphold their independence and sovereignty and to deal with the issues and interests of the Arab countries. It was previously named as the League of Arab States (Arab League Online, 2014).

\subsubsection{European Free Trade Association (EFTA)}

EFTA was established in 1960 by Switzerland and Norway as a free trade organization to act as an alternative trade bloc for European Countries that were unable or unwilling to join the former form of present EU. Now it has four members (Iceland, Liechtenstein, Norway, and Switzerland). In addition to keeping link, it operates in parallel with the EU to ensure greater trade liberalization among member countries (European Free Trade Association, 2014).

\subsubsection{Eurasian Economic Community (EAEC)}

EAEC was founded in 2000 to ensure freedom of movement without visa among member states. It originated from Customs Union of Belarus, Kazakhstan and Russia. It has six member states and a Common Economic Space. The Eurasian Economic Commission regulates the community. However, the Community has decided to 
end up in Eurasian Economic Union on 1 January 2015 (Eurasian Economic Community, 2014).

\subsubsection{Association of Southeast Asian Nations (ASEAN)}

ASEAN is a political and economic organization of ten Southeast Asian countries that have the sixth largest economy in the world. Being established in 1967 it aspired to accelerate economic growth, social progress and socio-cultural evolution of members, to protect regional peace and stability and to provide a platform for the member countries to discuss differences peacefully (Association of Southeast Asian Nations, 2014).

\subsubsection{Central European Free Trade Agreement (CEFTA)}

As a trade agreement between non-EU countries CEFTA started in 1994. It includes countries in Southeast Europe and presently has seven members. It attempt to consolidate democracy and free market economics by joining European political, economic, security and legal systems through mobilizing the efforts to integrate into Western European institutions (Central European Free Trade Agreement, 2014).

\subsubsection{North American Free Trade Agreement (NAFTA)}

NAFTA is a trilateral trading bloc of three North American countries- Canada, Mexico and United States established in 1994. It aims to remove restriction on movements of goods, services and investment among the member countries. NAFTA has the world's largest combined economy in terms of GDP (Naftanow.org, 2014).

\subsubsection{South Asian Association for Regional Cooperation (SAARC)}

SAARC was established in 1985 by seven country's governments of South Asia as an economic and geopolitical organization. It has now eight members who have the $3^{\text {rd }}$ largest combined economy. It attempts to foster economic welfare and socio-cultural development of the region and to develop collective self-reliance among the member countries (South Asian Association for Regional Cooperation, 2014).

\subsubsection{Pacific Islands Forum (PIF)}

Founded as the South Pacific Forum in 1971 and renamed as Pacific Islands Forum in 1999, PIF is an inter-governmental organization of the independent countries of the Pacific Ocean. It aims to enhance cooperation between the sixteen member states and international agencies. It also supports member governments, represents the interest of members and enhances the economic and social well-being of the people (Pacific Island Forum Secretariat, 2014).

\subsection{Results of Economic Integration in Economic and Management Literature}

Studies on the impact of regional integration on economic growth are bit scarce in numbers with few exceptions like Walz (1995, 1997a, 1997b, 1999). Those studies used the "General Equilibrium Model" and detected that the growth following integration virtually depends on many factors. Those factors are trade creation or trade diversion, the comparative advantage of each member, and initial trade barriers. Therefore of the factors which dictate the relationship between integration and growth are volatile and discrete in nature. Considering these issues, the literatures in this field significantly failed to interpret the exact impact of integration on growth. However, over the years there is a common believe among the experts that the potential impact of regional integration results trade liberalization and trade creation and growth through both dynamic and static effects (Baldwin, 1989). One of the most prominent dynamic effects which results ultimate growth is the economies of scale factors. To go further with this issue few experts stated that larger markets which resulted from regional integration enable firms to operate in larger scales thus economies of scales are obtained through this (Walz, 1997). In addition to that trade openness somewhat reduces the effect of domestic market size on economic growth, as integration resulted openness and openness resulted in larger market access for all the countries including smaller ones. In a different yet relevant study Puga and Venables (1998) detected the relationship between agreement and economic welfare. Their main focus was to investigate the effects of trade arrangements and openness among developed and developing countries. They conclude that unilateral liberalization is beneficial, but also that the gains from an integration agreement are likely to be larger.

Venables (1999) followed a different approach in compare to the traditional trade theories and added that human capital endowments coupled with trade agreements can resulted in economic growth and welfare. In addition to that the study also significantly pointed out that countries which have comparative advantages well above of the world average are more likely to be suffer less from trade diversion resulting from trade openness and agreements. One the other hand countries with lesser average will suffer more of trade diversion as result of weaker competitive regional position in terms of factors of productions. This study is a significant addition to the literature of regional integration and trade creation and also their overall impact on growth. In-depth evaluation of the outcome of the study reveals interesting yet important policy making perceptions. First of all it tells hat if 
a regional integration created among only developing countries then there is every chance that all of them will be benefited as they most likely possessing similar types of comparative advantages in world trade. On the other hand if such integration is created among few developed and developing countries then developing and under developed countries will suffer more due to trade diversion. This is simply because they do not possessing similar trade attraction and factor endowment capabilities in compare to the developed countries. Virtually, will suffer from trade diversion and as a result equal and universal growth of all the partner countries won't be ensured. This conclusion is somewhat contradictory and arbitrary to the result of NAFTA where both US, Canada and Mexico were benefiting due to the creation of regional trade integration. However, that also may be due to the fact that all of those three countries were specialized in different things like Canada in land availability, Mexico for cheap labor force and US for capital and technology. Those moderating factors somehow reduce the impact of discrete comparative advantages and income levels of those partner countries.

De Melo et al. (1992) and Vamvakidis (1998) found that for several integration agreements a dummy variable reflecting membership does not have a significant effect on growth. In a related paper, Vamvakidis (1999) addresses the question of whether countries engaging in unilateral liberalizations grow faster than countries that engage in regional integration agreements (RIA). Results show that economic growth is greater in countries that accomplish broad liberalization than in countries that engage in RIAs, specifically he finds that becoming a member of at least one RIA does not foster growth. In a relevant study on ASEAN countries Madani (2001) has identified less significant of integration on growth. That study used dummy variable in the context to test the relationship and find out that the growth effect is not significant among those countries. In summary, theory does not provide indications about the expected impact of regional integration on growth, although it is possible to indirectly extract some guidelines regarding the type of agreements that might have positive effects: those that include at least one developed partner. The empirical literature, by using a dummy variable to measure the impact of RIA membership, has ignored the fact that impacts are likely to depend on market size (Berthelon, 2004).

\subsection{Economic Growth}

Economic growth is a complex construct to define. Additionally, immeasurable distinction among countries in terms of society, culture, economic and political structure, institutions and policies, natural and physical resource endowment make it more difficult to define unanimously (Adelman, 1961). However, economic growth has been generally indicated by the level of national income or output that means the level of gross domestic product (GDP) (Ezeala-Harrison, 1996). It refers to the increase in the level of the market value of all goods and services produced within an economy over a period of time. Very often this increment is calculated after adjustment of the rate of inflation. Growth is also presented in per capita basis by dividing the total output by the total number of population. Thus, economic growth is the sustained level of increase in per capital real GDP over a period of time (Acemoglu, 2008). Economic growth is frequently used interchangeably with economic development. However, growth is the increase in output or income while, economic development is the process of improvement in productivity by which the goal of economic growth is achieved (Ezeala-Harrison, 1996).

\subsection{Factors Affecting Economic Growth}

There are different viewpoints about the factors which actually affect the economic growth. However, some key factors have been cited in most of the researches: capital or investment, labor or human capital, physical capital, research and development and knowledge. Khaledi and Shirazi (2013) suggested that high level of economic growth can be achieved by increasing capital, labor and total productivity of capital and labor. Moral-Benito (2007) pointed investment price, air distance to big cities and political rights as the most robust growth determinants. Bassanini and Scarpetta (2001) recommended for accumulation of physical capital, human capital, expenditure on research and development (R\&D), fiscal policy and development of financial system. Ndambiri et al. (2012) indicated that physical capital formation, export and human capital along with government expenditure, nominal discount rate and foreign aid significantly affect economic growth. Artelaris et al. (2007) identified investment and openness to trade as the most fundamental determinants. Barro and Sala-i-Martin (1995) focused on human capital, economic policies and macroeconomic conditions. Tolo (2011) spotted exports, investment, research and development, population growth, political uncertainty, deficit, inflation, trade openness, the current account balance and the frequency of crisis episodes as significant determinants of growth. Fisher (1993) selected inflation, fiscal policy, budget deficits and tax burdens as macroeconomic factors that can affect growth. Barro (1999) used level of per capita GDP, government consumption, rule of law, democracy, inflation rate, education, fertility rate, investment ratios and terms of trade to determine the economic growth of Chile. Lensink and Morrissey (2006) decided that Foreign Direct Investment (FDI) plays a pivotal role for economic growth. Rodrik (2000) highlighted five key institutions that not only affect economic growth directly, but also 
influence other determinants of growth like, physical and human capital, investment and technical changes. These institutions are: property rights, regulatory institutions and institutions for macroeconomic stabilization, social insurance and conflict management. Adelman (1961) indicated human resource acquisition of the economy, technological improvement, amount of capital investment, natural resource endowment and degree of its exploitation and managerial know-how as the determinants of economic growth. Along with capital accumulation technological progress and institutional and social factors have been positioned by Kibritcioglu (1997). Romer (1986) and Lucas (1988) recognized that growth rate depends on R\&D technology, the degree of firms' monopoly power and time horizon of investors. The significance of research and development $(\mathrm{R} \& \mathrm{D})$ has also been stressed by Lichtenberg (1992). On the other hand, quality of human capital has been considered as important by Brunetti et al. (1998) and Hanushek and Kimko (2000).

\subsection{Various Measurements of Economic Growth and Trade Liberalization}

Economic growth is a very relative term and matter of huge academic debate among economists and what actually meant by the terms economic growth. Factors that affect the economic growth also act as the measurement indicators of the actual level of growth of a particular country or region for a particular period of time. Besides, there are some more aspects that researchers have used for measuring economic growth. A very commonly used indicator is the level of national income either indicated by gross national product (GNP) or gross domestic product (GDP). To allow the comparability with other countries, national income is presented in per capita basis by dividing the total national income by the total population. It can also be presented form another point of view. When total income is replaced with total output and it is divided by the size of labor force, growth can also be measured by output per labor or labor productivity (Morrissey, 2006). Summers and Heston (1991) introduced an exchange rate adjusted measure of economic growth. Here, the concept of purchasing power parity is used to rescale the national income of countries and to facilitate cross-national comparison. Coe and Helpman (1995) and Helpman (1993) attempted to understand the dynamics of cross-country technology dissemination and concluded that knowledge inputs from scientists and engineers, R\&D, patents, knowledge spillovers and ideas are the drivers of economic growth. Focusing on income inequality with per capita income, Kuznets (1955) found an inverse relationship between these two (Morrissey, 2006). Solow (1956) suggested measuring the level of investment the accumulation of physical capital constituting the critical force of economic growth (Morrissey, 2006). Similar to economic growth, trade liberalization is also a relative term and therefore immensely difficult to measure. There are different mechanisms and techniques available to measure the level of trade liberalization. Few ratio analyses is extremely useful in this regard which not measures the trade liberalization but also sometimes measure trade liberalization and economic growth jointly. Some of those ratios for calculating both economic growth and trade liberalization are:

Real GDP Growth Rate: Real GDP growth rate simply is the growth rate of GDP in compare to the previous year. It is probably the most popular as well as commonly used techniques for measuring the degree of economic growth. It is also good comparative device as in straight forward manner it computes and shows how the economy is performing and surging in compare to the last year or sometimes last few years.

Import orientation Ratio: The import penetration ratio is the ratio of total import to the total GDP of a country for a particular period. It jointly expresses the trend in economic growth and also the trend of trade liberalization. The higher import orientation ratio means that the country is importing more and more goods which is shows the strength of the economy and its consumers. Increase in this ratio represents the fact that the domestic demand for foreign goods is increasing and simultaneously the economic growth is also happening.

Import Penetration Ratio: It is the ratio of aggregate imports to aggregate consumption [imports/(output + imports - exports)]. From the formula of the calculation of this ratio it is obvious that import penetration ratio represents the fraction of imported goods and services in the total consumption of a certain period. Higher import penetration ratio means that imported goods and services constitute a major portion of the total consumption. Whereas it shows the increase in the capabilities of the consumers but simultaneously it also represents the inability of domestic factors of production to produce enough goods for the consumers. Therefore, government and policy makers have to be cautious in policy making for utilizing this ratio for the betterment of the economy and the country.

Export Orientation Ratio: Export orientation ratio is the ratio of aggregate exports to GDP. It is a vital indicator of both trade liberalization and growth. That is mainly because it represents simultaneously the change in production and also change in the participation in international trade. Higher export orientation ratio indicates that the country is experiencing growth in export therefore signifies strong performance of domestic economy. At the same time increase in this ratio also underlined the fact that the respective country is orienting her more in 
international trade.

Ratio of Trade Share: The ratio of trade share, also known as the dependency ratio and measured by the ratio of exports plus imports to GDP. Trade share ratio indicates the current flows in the transactions in both capital and current account as a percentage of the gross output for a certain period of time. Therefore higher ratio of trade share simple portrays more trade liberalization and strong participation in international trade.

Collected Tariff Ratio: Collected tariff ratio is the ratio of import duties to total import. Higher collected tariff ratio simply indicates increase in imports and consequentially as well as increase in the capabilities of the domestic consumers.

Real Effective Exchange Rate: It is the trend in the change of exchange rate. While exchange rate is an important indicator hence influence international trade significantly. Strong performance of currency signify favorable position in the Balance of Payment but few economists also argued the declining in the value of currency sometimes also attracts foreign investors to invest more and thus increase in the employment and also contributes towards increasing the GDP.

Inflation Rate: Trend in the change of inflation rate again an important indicator of how the economy is performing. While a lower level and consistent rate of inflation signifies stable economy, volatile inflation rate portrays the contrasting picture.

\section{Relationship among Regional Integration, Trade Liberalization and Economic Growth}

Krieger-Boden, C. and Soltwedel (2010) reviewed and analyzed the concepts and actual measures of European integration and globalization in order to separate the effects of these two aspects. The authors also attempted to perform empirical analysis by operationalizing the integration processes. To reduce the endogeneity problem indices of regional integration and globalization have been searched, the collinearity between them and their workability have been discussed in an illustrative gravity model.

Naveh et al. (2012) took Iran and northern neighboring countries to analyze the effects of regional integration and extrovert policies on growth and welfare during 1995-2009. Findings indicated that, regional integrations had long-term economic integration effects. Economic liberalization and domestic investment were found to have a positive effect on gross domestic production and economic welfare. However, foreign investment was negatively related with economic growth. They also found that, the greater role played by trade in gross domestic production, the less society welfare will be. Narendra and Goel (2014) examined impact of regional economic integration on economic growth. To do so, the roles of income distribution, trade, poverty, employment etc. on various economies were determined. Results revealed that the impact of regional economic integration on economic growth, income distribution, trade, poverty and employment is neutral.

Using standard growth models for nearly 100 developing countries over 1970-2004Velde, D. W. (2011) empirically examined whether and how regional integration leads to convergence and growth in developing countries. This study found that regional integration increases trade and FDI which in fact promotes growth. It also found that integration initially raises regional income disparities but ultimately causes greater reduction of these disparities. However, deep regional integration was found to be harmful to growth. Berthelon (2004) attempted to identify the impact of size of countries in realizing the effects of regional integration. The author introduced a new measure of regional integration by taking into account the interacting country membership to a regional integration agreement and the partners' share of world GDP. The overall results indicated positive effects of integration on growth. The study also found that North-North agreements had significant growth effects, South-South agreements had ambiguous effects depending on the size and no clear indications for North-South agreements were found.

Dion (2004) quantitatively measured the influence of regional trade integration on productivity focusing on knowledge spillovers in a multi-country model. The study found that, a country is benefited by both the R\&D efforts of itself and its trading partners. Integration allows technology transfers and makes the countries interdependent in various aspects like: goods, services, people, capital and therefore ideas, knowledge, innovation, and technology. These spillovers and diffusions of R\&D can then spread across countries and sectors Negasi (2009) applied an augmented gravity model using panel data from 2000 to 2007 and random effect estimator methods to analyze trade creation and diversion effects of the Southern African Development Community (SADC). The results indicate that in fuel and minerals, and heavy manufacturing sectors, intraSADC trade is increasing while trade with rest of the world is decreasing. On the other hand, in agricultural and light manufacturing sectors trade is increasing between both members and non-member countries.

Ezaki and Nguyen (2008) applied a world CGE model to quantify the impact of regional economic integration in 
East Asia. Evaluating the potentials on growth, income distribution and poverty reduction in China, Indonesia, Thailand and Vietnam, they found that, free trade agreements in East Asia generally have positive effects of growth. These agreements have also improved income distribution and reduced poverty in other countries, though the impacts on China were found a little bit exceptional. Cameron (2010) showed the European Union (EU) as a model for regional integration. The author pointed that, though EU is the most comprehensive example of regional integration, it has experienced economic crisis several times which questions the integrity of integration. Social cohesion and political stability in Europe have been threatened and growth of Asia lagged EU and United States behind. However, the author opined that EU is still and will continue to a leading example of regional integration because it has been able to overcome the crisis situation just like other previous crises.

In his study on Asian countries focusing on the importance of improved governance coupled with economic integration contributing towards growth, Owen (2013) detected that improved government alongside with the proper policy making can make regional integration more effective and diversified and robust growth also can be obtained. Analyzing the existing regionalism or economic integration in Asian countries, Rai (2010) found that though integration has increased, sense of cooperation has not. Author opined that, the recent increment of FTAs may not actually increase trade volume, rather can reduce it. Therefore, it is required by the existing FTAs to integrate into a broader one to ensure potential gains from integration- author suggested. Using micro-founded gravity-type model of trade patterns Sousa (2011) investigated the ease of market access in global and regional trade and developed a new method to measure the level of difficulties faced by both developing and developed countries. This study estimated the impact of national borders on the access of Southern producers to Northern markets. It also found that the level of difficulties faced has been reduced during last thirty years. Najarzadeh and Shaghaghi (2006) studied the effect of regional integration on attracting foreign capitals using generalized pattern of attraction for eight MENA countries during 1995-2000. They found that there is a positive relationship between integration and foreign capital attraction for Islamic countries of MENA which is actually causing a greater degree of cooperation among these countries.

\section{Methodology}

Detecting the impact of regional integration on both trade liberalization and economic growth is certainly a big challenge. In order to mitigate that challenge we had to use tools and techniques that is effective for measuring both the dependent variables. For judging the impact of regional trade integration on economic liberalization and growth we have used eight ratio analysis and trends. Those are: Real GDP Growth Rate, Import Penetration Ratio, Import Orientation Ratio, Export Orientation Ratio, Ratio of Trade Share, Collected Tariff Ratio, Real Effective Exchange Rate and Inflation Rate. Those were selected after reviewing literature in the field of economics and international trade. The next important decision was to ensure the perfect methods for showing the real impact and also drawing comparison with countries which do not came forward in such platform. Our selected countries were from Europe. As we wanted to show the impact of integration, the first task is to measure the impact of integration (EU) on countries which are member of EU. There are 28 such countries which are member of EU and joined this integration over the years. Then, in order to portray the real impact we have presented the trends in those eight variables of participating 28 countries for two period of time. First period (mainly 1970-1991) is before integration and second period (1992-2013) is after integration. These techniques helped us to measure the impact correctly and also assisted to draw an effective comparative picture. In addition it was also important to find how other countries in the region are performing which are not parts of the EU. There are 21 such countries in Europe which are not member of the EU. We have showed the trend of those eight variables (1970-2013) for those 21 countries in order to draw a comparison among member and non-member countries.

\section{Discussion and Analysis}

\subsection{Impact of Regional Integration on Liberalization and Growth on EU Countries}

\subsubsection{Real GDP Growth}

Real GDP growth rate is certainly one of the best and widely used tools for judging the economic growth specially the trend. Our analysis shows that over the last forty four years, the EU countries have experienced an overall decline in real GDP growth. If we break down this in the period of before and after integration the picture is not really contrasting. Before the integration, that is, from 1970-1993 average overall GDP growth was 2.70 percent. While after integration, that means, from 1994-2013 average overall GDP growth rate was 2.61 percent. However, this outcome opens further areas for discussion. In-depth analyses of European economies reveal that barring few countries like Germany, France, Italy, The Netherlands and UK other economies are not really diversified in nature. While historically European countries benefitted from early industrialization and also early 
internationalization but as time goes their smaller market not really been surged and as a result economies were got stacked and stable in a certain situation. The impact of that factor may have been greater if such integration would not happen. Many economist and supporters of regional integration would say that they were integrating to reduce the economy stagnation impact and they were successful up to certain margin. Further breaking down analysis reveals that the five years' average figures for real GDP growth shows that it declined from 4.92 percent during 1970-1974 to -0.46 percent during 2009-2013. Five year averages for all countries were 4.92, $4.11,2.18,3.40,-1.09,3.56,3.43,3.90$ and -0.46 percent. Average for twenty four years for Belgium is 2.60 percent. For Denmark it is 2.04 percent, for France 2.85, Germany 2.54, Greece 2.68, Italy 2.89, Netherlands 2.70, Portugal 4.05, Spain 3.03, Sweden 1.81 and for United Kingdom twenty four years' average before integration was 2.22 percent. After integration, the average for twenty years in case of Belgium is 1.79 percent, of Denmark is 1.51 percent, France 1.57, Germany 1.39, Greece 1.22, Italy 0.74, Netherlands 1.94, Portugal 1.38, Spain 2.18, Sweden 2.65 and of United Kingdom, it is 2.35 percent.

Table 1. Average GDP growth rates (\%), in EU, 1970-2013

\begin{tabular}{|c|c|c|c|c|c|c|c|c|c|}
\hline Countries & $1970-1974$ & 1975-1979 & 1980-1984 & 1985-1989 & $1990-1993$ & 1994-1998 & 1999-2003 & 2004-2008 & 2009-2013 \\
\hline Austria & 5.14 & 2.89 & 1.32 & 2.67 & 2.60 & 2.73 & 2.12 & 2.76 & 0.39 \\
\hline Belgium & 5.06 & 2.03 & 1.51 & 2.79 & 1.38 & 2.54 & 2.04 & 2.31 & 0.27 \\
\hline Bulgaria & - & - & 3.52 & 4.12 & -6.58 & -0.23 & 4.41 & 6.44 & -0.36 \\
\hline Croatia & - & - & - & - & - & 4.81 & 3.32 & 4.10 & -2.46 \\
\hline Cyprus & - & 13.58 & 5.73 & 6.45 & 4.56 & 4.25 & 3.59 & 4.20 & -1.55 \\
\hline $\begin{array}{l}\text { Czech } \\
\text { Republic }\end{array}$ & - & - & - & - & -4.02 & 2.52 & 2.98 & 5.47 & -0.43 \\
\hline Denmark & 2.43 & 2.62 & 1.83 & 1.94 & 1.20 & 3.36 & 1.53 & 1.79 & -0.63 \\
\hline Estonia & - & - & - & - & - & 5.45 & 6.01 & 5.73 & 0.56 \\
\hline Finland & 5.13 & 2.49 & 3.17 & 3.95 & -2.45 & 4.48 & 3.07 & 3.42 & -0.95 \\
\hline France & 5.38 & 2.84 & 1.55 & 3.02 & 1.12 & 2.18 & 2.13 & 1.81 & 0.17 \\
\hline Germany & 3.28 & 2.92 & 1.19 & 2.72 & 2.82 & 1.71 & 1.22 & 1.98 & 0.66 \\
\hline Greece & 5.52 & 5.34 & -0.22 & 1.77 & 0.55 & 2.69 & 4.30 & 3.10 & -5.20 \\
\hline Hungary & 5.96 & 4.90 & 1.86 & 1.20 & -4.76 & 2.36 & 3.90 & 2.73 & -0.94 \\
\hline Ireland & 4.74 & 5.10 & 2.56 & 3.67 & 4.11 & 9.06 & 7.15 & 3.72 & -1.09 \\
\hline Italy & 4.69 & 3.36 & 1.82 & 3.29 & 0.88 & 1.90 & 1.47 & 1.08 & -1.51 \\
\hline Latvia & 6.31 & 4.41 & 4.33 & 3.49 & -14.41 & 3.61 & 6.66 & 7.45 & -0.78 \\
\hline Lithuania & - & - & - & - & -14.39 & 2.76 & 5.20 & 7.15 & -0.09 \\
\hline Luxembourg & 4.71 & 0.79 & 2.12 & 7.00 & 5.00 & 3.84 & 5.03 & 4.08 & 0.28 \\
\hline Malta & 5.62 & 14.08 & 2.60 & 5.43 & 5.43 & 5.23 & 2.58 & 2.71 & 1.38 \\
\hline Netherlands & 4.51 & 2.24 & 1.27 & 3.03 & 2.40 & 3.54 & 2.19 & 2.68 & -0.65 \\
\hline Poland & - & - & - & - & -0.25 & 6.11 & 3.06 & 5.42 & 2.72 \\
\hline Portugal & 7.92 & 3.32 & 1.26 & 5.45 & 1.84 & 3.70 & 1.96 & 1.23 & -1.37 \\
\hline Romania & - & - & 4.19 & -0.64 & -6.46 & 0.85 & 3.35 & 7.25 & -0.32 \\
\hline $\begin{array}{l}\text { Slovak } \\
\text { Republic }\end{array}$ & - & - & - & 2.65 & -6.92 & 5.56 & 2.85 & 7.26 & 1.04 \\
\hline Slovenia & - & - & - & - & -3.84 & 4.22 & 3.86 & 4.92 & -1.93 \\
\hline Spain & 6.10 & 1.64 & 1.38 & 4.21 & 1.56 & 3.19 & 3.85 & 3.06 & -1.37 \\
\hline Sweden & 3.29 & 1.52 & 1.91 & 2.68 & -0.90 & 3.30 & 3.04 & 2.88 & 1.41 \\
\hline $\begin{array}{l}\text { United } \\
\text { Kingdom }\end{array}$ & 2.81 & 2.09 & 0.99 & 3.90 & 1.07 & 3.98 & 3.15 & 2.36 & -0.07 \\
\hline Overall & 4.92 & 4.11 & 2.18 & 3.40 & -1.09 & 3.56 & 3.43 & 3.90 & -0.46 \\
\hline
\end{tabular}

Source: Based on World Bank Data (2014).

\subsubsection{Trends in Import Orientation Ratio}

Import orientation ratio as mentioned earlier simultaneously represents trade liberalization and growth. Higher import penetration simply indicates that the economy is liberal in international trade and also represents the greater capabilities of domestic consumers for purchasing foreign goods. In other way around some would also argued that sometimes it also represents lack of investment in domestic sectors and also incapability of domestic 
factors of production in producing enough quality goods to fulfill the ever increasing demand of high quality goods of local consumers. Our analysis on EU member countries over the last forty years reveals that Import orientation ratio has been increased. During this entire period import orientation has grown around 69.20 percent for EU countries. Before integration the growth rate was around 27.78 percent and after integration it was 23.59 percent. This is an interesting outcome considering the fact that the ratio is expected to increase after integration. However, still the growth rate is very high in compare to the other parts or region of the world. This presents the simple fact and notion that the EU region has become liberal over the years and open for the member countries. Near about 70 percent growth in forty years is a huge figure and even if the rate is 23 percent after integration this is commendable to say the least. If we try to find out explanation behind slight reduction in the import orientation after integration it is evident that this is even before the integration those countries were not close economies and they were engaged in international business. Over the years some economies gained more economies capabilities and diversities and that caused the import figure to bogged down a bit, But, importantly that not because trade protectionism but because of increase in capabilities and production diversities. The average of the import orientation ratio for EU countries from 1970-1993 was 39.58 percent and from 1994-2013 the average was 53.17 percent. The five years' averages for all EU countries were 33.84, 39.02, 41.55, 40.25, 43.24, 46.33, 51.96, 57.14 and 57.26percent respectively. After integration, for the period of 1994-2013, Belgium (72.87 percent), Bulgaria (61.58percent), Czech Republic (60.16percent), Estonia (79.60percent), Hungary (67.21 percent), Ireland (73.23 percent), Lithuania (61.15 percent), Luxembourg (124.24 percent), Malta (86.83 percent), Netherlands (62.92 percent) and Slovak Republic (74.82 percent) were the countries with highest average import penetration ratios. Whereas, before integration, from 1970-1993 the ratios for these countries were, for Belgium 57.93 percent, Bulgaria 40.83 percent, Czech Republic 42.08 percent, Estonia 70.31 percent, Hungary 38.36percent, Ireland 51.28 percent, Lithuania 48.00 percent, Luxembourg 83.25 percent, Malta 81.67 percent, Netherlands 49.65 percent and Slovak Republic 46.01 percent.

Table 2. Average import orientation (\% of GDP), in EU, 1970-2013

\begin{tabular}{|c|c|c|c|c|c|c|c|c|c|}
\hline Countries & 1970-1974 & 1975-1979 & 1980-1984 & 1985-1989 & 1990-1993 & 1994-1998 & 1999-2003 & 2004-2008 & 2009-2013 \\
\hline Austria & 28.89 & 31.94 & 34.78 & 34.55 & 35.43 & 37.55 & 43.98 & 51.11 & 51.31 \\
\hline Belgium & 48.94 & 52.46 & 63.92 & 63.08 & 62.06 & 63.13 & 70.94 & 77.00 & 80.40 \\
\hline Bulgaria & - & - & 34.72 & 44.67 & 43.68 & 52.78 & 57.78 & 71.15 & 64.61 \\
\hline Croatia & - & - & - & - & 64.62 & 44.18 & 46.80 & 49.33 & 41.72 \\
\hline Cyprus & - & 62.75 & 64.34 & 54.18 & 55.69 & 51.23 & 51.79 & 52.65 & 46.06 \\
\hline $\begin{array}{l}\text { Czech } \\
\text { Republic }\end{array}$ & - & - & - & - & 42.08 & 51.23 & 60.04 & 63.08 & 66.31 \\
\hline Denmark & 31.54 & 32.76 & 36.11 & 33.80 & 31.99 & 34.07 & 39.49 & 47.00 & 47.20 \\
\hline Estonia & - & - & - & - & 70.31 & 79.49 & 80.16 & 79.74 & 79.00 \\
\hline Finland & 26.11 & 26.87 & 29.77 & 25.45 & 24.78 & 30.03 & 31.89 & 39.11 & 39.65 \\
\hline France & 17.00 & 19.73 & 23.76 & 22.20 & 21.35 & 22.17 & 26.05 & 27.65 & 28.33 \\
\hline Germany & 18.16 & 21.63 & 25.61 & 24.18 & 24.30 & 24.56 & 31.48 & 38.30 & 43.08 \\
\hline Greece & 21.23 & 24.76 & 30.05 & 29.35 & 29.18 & 28.46 & 36.22 & 35.42 & 31.85 \\
\hline Hungary & 36.25 & 45.75 & 39.05 & 37.28 & 32.28 & 49.19 & 69.71 & 75.06 & 80.00 \\
\hline Ireland & 43.17 & 53.88 & 55.52 & 51.64 & 52.40 & 66.10 & 77.51 & 70.69 & 79.99 \\
\hline Italy & 17.80 & 21.06 & 22.92 & 19.29 & 18.14 & 20.88 & 24.41 & 27.45 & 28.03 \\
\hline Latvia & - & - & - & - & 51.14 & 51.56 & 50.93 & 61.40 & 54.42 \\
\hline Lithuania & - & - & - & - & 48.00 & 59.31 & 54.08 & 66.11 & 67.73 \\
\hline Luxembourg & 74.20 & 79.35 & 86.20 & 90.99 & 86.03 & 94.90 & 121.46 & 138.58 & 142.02 \\
\hline Malta & 76.95 & 85.68 & 78.73 & 78.77 & 89.83 & 90.20 & 85.39 & 86.48 & 84.23 \\
\hline Netherlands & 44.92 & 46.48 & 53.34 & 52.29 & 51.61 & 54.94 & 59.84 & 63.83 & 73.06 \\
\hline Poland & - & - & - & - & 20.82 & 24.52 & 32.49 & 41.47 & 44.15 \\
\hline Portugal & 27.25 & 26.72 & 35.33 & 33.45 & 33.78 & 34.83 & 37.20 & 39.15 & 38.67 \\
\hline Romania & - & - & - & - & 27.98 & 32.73 & 38.98 & 43.81 & 42.17 \\
\hline $\begin{array}{l}\text { Slovak } \\
\text { Republic }\end{array}$ & - & - & - & 34.07 & 54.96 & 61.93 & 75.13 & 84.12 & 80.27 \\
\hline Slovenia & - & - & - & - & 66.66 & 52.69 & 54.51 & 66.08 & 63.92 \\
\hline Spain & 14.39 & 15.25 & 18.91 & 18.73 & 19.19 & 23.73 & 29.98 & 31.89 & 30.17 \\
\hline Sweden & 24.31 & 27.57 & 31.18 & 30.50 & 27.60 & 33.49 & 38.14 & 42.52 & 42.38 \\
\hline $\begin{array}{l}\text { United } \\
\text { Kingdom }\end{array}$ & 24.11 & 27.71 & 25.16 & 26.57 & 24.87 & 27.51 & 28.40 & 29.90 & 32.59 \\
\hline Overall & 33.84 & 39.02 & 41.55 & 40.25 & 43.24 & 46.33 & 51.96 & 57.14 & 57.26 \\
\hline
\end{tabular}

Source: Based on World Bank Data (2014). 


\subsubsection{Trends in Import Penetration Ratio}

Similar to the Import Orientation ratio, import orientation ratio also simultaneously interprets economic growth and liberalization. It mainly represents the portion of imported goods as percentage of total consumption in a certain period of time. Increase in this ratio portrays that the economy is getting liberal day by day and also consumers are enjoying more and more foreign goods. However, sometimes it also may be negative as excessive imports may create debacle in domestic sectors and initiate problems like investment vacuum and unemployment Our data analysis on the EU countries over the last forth years period exposes the fact that import penetration ratio has also been increased for the EU countries over the period of 1970-2013. The overall ratio of import penetration was highest during the period of 2004-2008 (58.17 percent). However, the overall average ratio for all the twenty eight EU countries for the forty four years period was 45.38 percent while this ratio before integration was 38.93 percent and after integration, it was 53.45 percent. This simply means that EU countries were becoming more liberal as a result of integration and their consumers were increasingly using foreign imported goods as a major fraction of their consumption. The growth of this ratio for the entire period was 67.60 percent. Unlike the absolute average figure, the growth rate was lower after integration ( 20.93 percent) than the growth rate before integration ( 24.60 percent). Overall averages for the twenty eight countries were $33.58,37.87$, $40.62,40.76,41.84,46.54,52.79,58.17$ and 56.28 each of the five years interval within the total period. Before integration, the average import penetration ratio for Luxembourg was 95.85 percent and for Malta was 72.51 percent. Besides, for Austria it was 32.74 percent, for Belgium 58.33 percent, Denmark 33.28 percent, Finland 26.60 percent, Hungary 37.77 percent, Ireland 49.70 percent, Netherlands 51.15 percent, Portugal 28.82 percent, Sweden 28.71 percent and for United Kingdom it was 25.67 percent. After integration, the ratios for the countries were for Austria 47.41 percent, Belgium 75.30 percent, Denmark 44.00 percent, Finland 37.02 percent, Hungary 67.35 percent, Ireland 85.73 percent, Luxembourg 167.37 percent, Malta 83.78 percent, Netherlands 67.70 percent, Portugal 34.90 percent, Sweden 41.93 percent and for United Kingdom it was 29.14 percent. All these figures suggest an increasing trend.

Table 3. Average import penetration (\% of Total Consumption), in EU, 1970-2013

\begin{tabular}{|c|c|c|c|c|c|c|c|c|c|}
\hline Countries & 1970-1974 & 1975-1979 & 1980-1984 & 1985-1989 & 1990-1993 & 1994-1998 & 1999-2003 & 2004-2008 & 2009-2013 \\
\hline Austria & 28.79 & 31.35 & 34.22 & 34.56 & 35.29 & 37.28 & 45.20 & 53.74 & 53.41 \\
\hline Belgium & 49.85 & 52.04 & 63.04 & 64.26 & 63.50 & 65.54 & 74.17 & 79.73 & 81.76 \\
\hline Bulgaria & - & - & 35.36 & 44.00 & 42.25 & 53.94 & 53.75 & 60.74 & 62.92 \\
\hline Croatia & - & - & - & - & - & 41.33 & 44.24 & 46.17 & 41.47 \\
\hline Cyprus & - & 52.89 & 56.45 & 51.01 & 52.06 & 50.60 & 52.01 & 50.05 & - \\
\hline $\begin{array}{l}\text { Czech } \\
\text { Republic }\end{array}$ & - & - & - & - & 43.39 & 49.71 & 59.24 & 64.59 & 69.65 \\
\hline Denmark & 30.68 & 31.63 & 36.18 & 34.09 & 33.93 & 35.48 & 42.01 & 48.76 & 49.74 \\
\hline Estonia & - & - & - & - & - & 72.29 & 76.31 & 74.24 & 81.60 \\
\hline Finland & 25.60 & 26.72 & 29.90 & 25.44 & 25.01 & 32.35 & 34.95 & 41.08 & 39.72 \\
\hline France & 17.07 & 19.80 & 23.48 & 22.05 & 21.39 & 22.63 & 26.40 & 27.37 & 27.71 \\
\hline Germany & 17.94 & 21.12 & 24.74 & 24.02 & 24.25 & 24.79 & 32.23 & 40.70 & 45.63 \\
\hline Greece & 19.53 & 23.07 & 27.93 & 27.01 & 26.18 & 25.89 & 32.01 & 31.61 & 29.73 \\
\hline Hungary & 35.69 & 43.25 & 39.24 & 37.71 & 31.76 & 48.84 & 67.99 & 74.39 & - \\
\hline Ireland & 39.63 & 48.79 & 51.35 & 53.65 & 56.44 & 74.75 & 91.35 & 79.31 & - \\
\hline Italy & 17.62 & 21.20 & 22.64 & 19.34 & 18.31 & 21.71 & 24.70 & 27.37 & 28.02 \\
\hline Latvia & - & - & - & - & 55.78 & 48.69 & 46.44 & 52.44 & - \\
\hline Lithuania & - & - & - & - & 45.83 & 54.23 & 50.75 & 60.14 & - \\
\hline Luxembourg & 91.91 & 89.83 & 93.32 & 104.09 & 101.19 & 117.08 & 152.34 & 194.81 & 205.26 \\
\hline Malta & 62.40 & 77.97 & 70.97 & 71.25 & 81.79 & 82.05 & 83.41 & 84.18 & - \\
\hline Netherlands & 45.89 & 47.32 & 55.22 & 53.98 & 53.91 & 58.07 & 63.44 & 69.42 & 79.87 \\
\hline Poland & - & - & - & - & 21.18 & 24.13 & 31.13 & 40.50 & 44.20 \\
\hline Portugal & 25.52 & 24.24 & 31.64 & 31.79 & 31.44 & 32.32 & 34.00 & 35.94 & 37.33 \\
\hline Romania & - & - & - & - & 26.17 & 30.76 & 36.69 & 39.26 & 40.36 \\
\hline $\begin{array}{l}\text { Slovak } \\
\text { Republic }\end{array}$ & - & - & - & - & 52.51 & 59.00 & 71.63 & 81.70 & - \\
\hline Slovenia & - & - & - & - & 72.50 & 52.45 & 53.72 & 65.13 & - \\
\hline Spain & 14.21 & 14.97 & 18.76 & 18.70 & 18.74 & 23.79 & 29.28 & 30.18 & 30.09 \\
\hline
\end{tabular}




\begin{tabular}{llllllllll}
\hline Sweden & 24.69 & 27.64 & 31.69 & 31.24 & 28.20 & 35.79 & 40.84 & 46.03 & 45.06 \\
United & 23.83 & 27.76 & 25.62 & 26.23 & 24.71 & 27.59 & 27.81 & 29.15 & 32.00 \\
$\begin{array}{l}\text { Kingdom } \\
\text { Overall }\end{array}$ & $\mathbf{3 3 . 5 8}$ & $\mathbf{3 7 . 8 7}$ & $\mathbf{4 0 . 6 2}$ & $\mathbf{4 0 . 7 6}$ & $\mathbf{4 1 . 8 4}$ & $\mathbf{4 6 . 5 4}$ & $\mathbf{5 2 . 7 9}$ & $\mathbf{5 8 . 1 7}$ & $\mathbf{5 6 . 2 8}$ \\
\hline
\end{tabular}

Source: Based on World Bank Data (2014).

\subsubsection{Trends in Export Orientation Ratio}

Export orientation ratio is the ratio of total exports to total GDP. Increment in this ratio indicates surge in domestic production, domestic economy and also showing that the economy is an open one rather than closed. Our research exposed that average of the export orientation ratios for EU countries shows an ever increasing trend for the whole period of forty four years. The rate of increments from each five year period to next were $12.09,9.42,1.30,8.70,6.50,12.39,8.29$ and 4.72 percent starting from 1970-1974 to 2009-2013. Average growth rate for the whole period was 83.33 percent. Again, growth before integration was 35.06 percent and after integration was 24.47 percent. It clearly shows that integration is resulting constant increase in export which may not be possible if those countries were not together. Inner and in-depth evaluation of this outcome persist us to describe the traditional static and dynamic effect of integration. Surge in export among most of the member countries reveals that all of them are benefiting from those two effects. While static effect made it possible for them to operate in a larger market that they normally use to be. Capabilities like economies of scale which are obtained through the static effects are generating dynamic effects. As a result they are now more capable in exporting higher quality goods in comparatively lower price and obtains increasing market share in larger outside lucrative markets like BRICS or N11 countries. This analysis obviously supports the notion that EU helping the member countries in diversified ways and generating growth which may not be possible for those economies specially which lacks multidimensional economic and geographic capabilities. Again, for all other EU countries except Croatia, Latvia and Slovenia average export orientation ratio was greater after integration than it was before integration. On the other hand, Luxembourg (52.68 percent), Ireland (39.77 percent), Hungary (29.98 percent) and Slovak Republic (29.51 percent) were found to have impressive differentials between the average export orientation ratios of after and before integration. Moreover, France, Germany, Greece, Italy, Poland, Portugal, Romania, Spain and United Kingdom had much lower average export orientation ratios both before and after integration. Average of the ratios for each of the five years periods were 31.92 (1970-1974), 35.78 (1975-1979), 39.15 (1980-1984), 39.66 (1985-1989), 43.11 (1990-1993), 45.91 (1994-1998), 51.60 (1999-2003), 55.88 (2004-2008) and 58.52 percent (2009-2013). Gross average for the entire period was 44.61 percent. Before integration the average was 37.92 percent and after integration 52.98 percent.

Table 4. Average export orientation ratio (\% of GDP), in EU, 1970-2013

\begin{tabular}{llllllllll}
\hline Countries & $\mathbf{1 9 7 0 - 1 9 7 4}$ & $\mathbf{1 9 7 5 - 1 9 7 9}$ & $\mathbf{1 9 8 0 - 1 9 8 4}$ & $\mathbf{1 9 8 5 - 1 9 8 9}$ & $\mathbf{1 9 9 0 - 1 9 9 3}$ & $\mathbf{1 9 9 4 - 1 9 9 8}$ & $\mathbf{1 9 9 9 - 2 0 0 3}$ & $\mathbf{2 0 0 4 - 2 0 0 8}$ & $\mathbf{2 0 0 9 - 2 0 1 3}$ \\
\hline Austria & 28.54 & 30.08 & 33.17 & 34.57 & 35.04 & 36.77 & 46.65 & 55.97 & 55.26 \\
Belgium & 50.84 & 51.68 & 62.43 & 64.92 & 64.35 & 66.80 & 75.32 & 80.47 & 82.10 \\
Bulgaria & - & - & 36.58 & 43.12 & 40.48 & 54.83 & 50.23 & 54.27 & 61.66 \\
Croatia & - & - & - & - & 63.22 & 37.17 & 41.03 & 42.49 & 41.06 \\
Cyprus & - & 44.01 & 50.30 & 48.12 & 48.88 & 50.02 & 52.16 & 47.50 & 40.19 \\
Czech & - & - & - & - & 45.18 & 48.19 & 58.72 & 65.41 & 71.01 \\
Republic & & & & & & & & \\
Denmark & 28.77 & 29.21 & 36.28 & 34.68 & 37.73 & 38.07 & 45.46 & 50.68 & 52.28 \\
Estonia & - & - & - & - & 66.27 & 69.53 & 75.00 & 72.32 & 82.43 \\
Finland & 24.16 & 26.31 & 30.22 & 25.36 & 25.49 & 37.17 & 40.63 & 43.95 & 39.87 \\
France & 17.49 & 20.09 & 22.58 & 21.52 & 21.57 & 24.15 & 27.39 & 26.67 & 26.09 \\
Germany & 16.91 & 19.25 & 22.08 & 23.52 & 24.13 & 25.47 & 33.79 & 44.14 & 48.64 \\
Greece & 12.53 & 17.43 & 22.39 & 20.68 & 17.77 & 18.56 & 23.13 & 23.48 & 24.59 \\
Hungary & 34.82 & 40.01 & 39.58 & 38.51 & 30.74 & 48.12 & 67.17 & 74.00 & 86.30 \\
Ireland & 34.52 & 43.66 & 47.34 & 55.35 & 59.44 & 77.63 & 92.68 & 81.54 & 100.13 \\
Italy & 17.03 & 21.72 & 21.74 & 19.57 & 19.07 & 24.71 & 25.56 & 27.20 & 27.97 \\
Latvia & - & - & - & - & 59.04 & 45.99 & 41.31 & 44.37 & 52.18 \\
Lithuania & - & - & - & - & 46.91 & 49.88 & 47.40 & 56.25 & 66.43 \\
Luxembourg & 92.98 & 90.98 & 93.72 & 103.50 & 101.02 & 114.00 & 141.74 & 167.16 & 172.83 \\
\hline & & & & & & & &
\end{tabular}




\begin{tabular}{|c|c|c|c|c|c|c|c|c|c|}
\hline Malta & 53.75 & 75.79 & 67.46 & 68.19 & 79.94 & 80.32 & 83.17 & 83.74 & 86.86 \\
\hline Netherlands & 46.99 & 48.24 & 56.69 & 55.38 & 55.90 & 60.33 & 65.51 & 71.86 & 81.50 \\
\hline Poland & - & - & - & - & 22.59 & 23.30 & 28.06 & 39.12 & 44.24 \\
\hline Portugal & 20.72 & 16.45 & 23.59 & 28.35 & 26.33 & 27.11 & 27.86 & 30.25 & 34.87 \\
\hline Romania & - & - & - & - & 21.28 & 26.49 & 32.81 & 32.19 & 37.61 \\
\hline $\begin{array}{l}\text { Slovak } \\
\text { Republic }\end{array}$ & - & - & - & 31.11 & 49.85 & 57.17 & 70.26 & 81.12 & 80.43 \\
\hline Slovenia & - & - & - & - & 74.05 & 52.15 & 53.00 & 64.65 & 64.93 \\
\hline Spain & 13.34 & 13.50 & 18.05 & 18.62 & 16.78 & 23.98 & 27.58 & 26.26 & 29.78 \\
\hline Sweden & 25.95 & 27.83 & 32.70 & 32.87 & 29.72 & 39.89 & 44.76 & 50.18 & 48.33 \\
\hline $\begin{array}{l}\text { United } \\
\text { Kingdom }\end{array}$ & 23.28 & 27.87 & 26.99 & 25.26 & 24.23 & 27.76 & 26.29 & 27.32 & 30.74 \\
\hline Overall & 31.92 & 35.78 & 39.15 & 39.66 & 43.11 & 45.91 & 51.60 & 55.88 & $\mathbf{5 8 . 5 2}$ \\
\hline
\end{tabular}

Source: Based on World Bank Data (2014).

\subsubsection{Trends in Ratio of Trade Share}

Ratio of trade share is the ratio of import plus export to total GDP. It represents the trade liberalization and also a real measure of participation in international trade. Whereas least participating nations like Bhutan will have very small trade share ratio highly involved nation like the Netherlands is likely to have a higher ratio of trade share. The significance of this ratio is diversified as it indicates the trend of different important variables like growth, economic capabilities and diversity. Increase in integration theoretically should result in increase in the ratio of trade share. This is simply because integration increases trade at least among member countries (static effect) and also synergies trade among non-member countries (dynamic effects). The overall average ratios for all twenty eight countries were 90.36 percent and the growth rate was 77.80 percent (1970-2013). Absolute average before integration (1970-1993) was 77.50 percent and the growth was 31.31 percent. After integration (1994-2013) average ratio of trade share was 106.44 percent and the growth rate was 26.74 percent. This clearly indicates that regional integration resulting trade liberalization and also accelerating the orientation in international trade. Five years averages for all EU countries along with period to period growth rates were 65.76, 74.80 (13.75), 80.70 (7.89), 79.91 (-0.98), 86.35 (8.06), 92.25 (6.83), 103.55 (12.25), 113.02 (9.14) and 116.92 (3.45) percent. Being top at the list, Luxembourg (222.08) and some other countries like Belgium (131.31), Bulgaria (102.02), Cyprus (103.78), Czech Republic (115.38), Estonia (153.57), Hungary (100.56), Ireland (126.14), Latvia (101.74), Lithuania (111.24), Malta (158.70), Netherlands (116.05), Slovak Republic (129.82) and Slovenia (121.12) had greater share of GDP as trade than others for the whole period.

Table 5. Average ratio of trade share (\% of GDP), in EU, 1970-2013

\begin{tabular}{llllllllll}
\hline Countries & $\mathbf{1 9 7 0 - 1 9 7 4}$ & $\mathbf{1 9 7 5 - 1 9 7 9}$ & $\mathbf{1 9 8 0 - 1 9 8 4}$ & $\mathbf{1 9 8 5 - 1 9 8 9}$ & $\mathbf{1 9 9 0 - 1 9 9 3}$ & $\mathbf{1 9 9 4 - 1 9 9 8}$ & $\mathbf{1 9 9 9 - 2 0 0 3}$ & $\mathbf{2 0 0 4 - 2 0 0 8}$ & $\mathbf{2 0 0 9 - 2 0 1 3}$ \\
\hline Austria & 57.44 & 62.03 & 67.95 & 69.13 & 70.47 & 74.33 & 90.63 & 107.08 & 106.58 \\
Belgium & 99.78 & 104.13 & 126.34 & 128.01 & 126.41 & 129.93 & 146.25 & 157.47 & 162.49 \\
Bulgaria & - & - & 71.30 & 87.79 & 84.16 & 107.60 & 108.01 & 125.42 & 126.27 \\
Croatia & - & - & - & - & 127.85 & 81.35 & 87.83 & 91.82 & 82.78 \\
Cyprus & - & 106.76 & 114.64 & 102.30 & 104.58 & 101.25 & 103.95 & 100.15 & 86.25 \\
Czech & - & - & - & - & 87.26 & 99.42 & 118.76 & 128.49 & 137.33 \\
Republic & & & & & & & & & \\
Denmark & 60.31 & 61.98 & 72.39 & 68.48 & 69.72 & 72.14 & 84.95 & 97.68 & 99.48 \\
Estonia & - & - & - & - & 136.58 & 149.02 & 155.16 & 152.06 & 161.43 \\
Finland & 50.27 & 53.18 & 60.00 & 50.82 & 50.27 & 67.20 & 72.52 & 83.06 & 79.52 \\
France & 34.49 & 39.82 & 46.34 & 43.71 & 42.92 & 46.33 & 53.44 & 54.32 & 54.42 \\
Germany & 35.07 & 40.88 & 47.69 & 47.71 & 48.42 & 50.03 & 65.27 & 82.44 & 91.72 \\
Greece & 33.76 & 42.19 & 52.44 & 50.03 & 46.95 & 47.02 & 59.35 & 58.90 & 56.44 \\
Hungary & 71.07 & 85.76 & 78.63 & 75.79 & 63.02 & 97.31 & 136.88 & 149.06 & 166.30 \\
Ireland & 77.69 & 97.54 & 102.86 & 106.98 & 111.84 & 143.73 & 170.19 & 152.23 & 180.12 \\
Italy & 34.83 & 42.79 & 44.66 & 38.86 & 37.21 & 45.59 & 49.98 & 54.65 & 56.00 \\
Latvia & - & - & - & - & 110.17 & 97.55 & 92.24 & 105.77 & 106.60 \\
Lithuania & - & - & - & - & 94.90 & 109.18 & 101.48 & 122.36 & 134.16 \\
\hline
\end{tabular}




\begin{tabular}{|c|c|c|c|c|c|c|c|c|c|}
\hline Luxembourg & 167.18 & 170.33 & 179.93 & 194.49 & 187.06 & 208.90 & 263.20 & 305.74 & 314.86 \\
\hline Malta & 130.70 & 161.48 & 146.19 & 146.96 & 169.77 & 170.52 & 168.56 & 170.22 & 171.08 \\
\hline Netherlands & 91.92 & 94.72 & 110.03 & 107.67 & 107.51 & 115.28 & 125.35 & 135.70 & 154.56 \\
\hline Poland & - & - & - & - & 43.40 & 47.82 & 60.56 & 80.58 & 88.39 \\
\hline Portugal & 47.97 & 43.16 & 58.92 & 61.80 & 60.11 & 61.94 & 65.06 & 69.39 & 73.54 \\
\hline Romania & - & - & - & - & 49.26 & 59.22 & 71.79 & 75.99 & 79.78 \\
\hline $\begin{array}{l}\text { Slovak } \\
\text { Republic }\end{array}$ & - & - & - & 65.18 & 104.81 & 119.10 & 145.38 & 165.24 & 160.70 \\
\hline Slovenia & - & - & - & - & 140.70 & 104.84 & 107.50 & 130.72 & 128.85 \\
\hline Spain & 27.73 & 28.75 & 36.96 & 37.35 & 35.97 & 47.71 & 57.57 & 58.15 & 59.95 \\
\hline Sweden & 50.26 & 55.40 & 63.88 & 63.37 & 57.31 & 73.38 & 82.90 & 92.69 & 90.71 \\
\hline $\begin{array}{l}\text { United } \\
\text { Kingdom }\end{array}$ & 47.38 & 55.58 & 52.15 & 51.82 & 49.09 & 55.28 & 54.69 & 57.22 & 63.33 \\
\hline Overall & 65.76 & 74.80 & 80.70 & 79.91 & 86.35 & 92.25 & 103.55 & 113.02 & 116.92 \\
\hline
\end{tabular}

Source: Based on World Bank Data (2014).

\subsubsection{Trends in Collected Tariff Ratios}

Collected tariff ratio is the ratio of import duties to total import. Both before and after integration, all other EU countries, except Croatia had the same average tariff collection ratio as a percentage of import during each period. Data were unavailable from 1970 to 1984 . From 1985 to 2013 this ratio for each of the five years period were 4.66 (1985-1989), 3.32 (1990-1993), 4.19 (1994-1998), 3.32 (1999-2003), 2.34 (2004-2008) and 1.80 (2009-2013). But, for the total period (1985-2013), average tariff collection ratio for all countries was 3.27. Another aspect can be noticed that, though tariff collection ratio increased from the period of 1985-1989 to the period of 1990-1993, after integration, it continuously declined (by 57.04 percent from 1994 to 2013). This is primarily because of regional integration reducing tariff rates.

Table 6. Average tariff collection ratio (\% of Total Imports), in EU, 1970-2013

\begin{tabular}{|c|c|c|c|c|c|c|c|c|c|}
\hline Countries & $1970-1974$ & 1975-1979 & 1980-1984 & 1985-1989 & $1990-1993$ & 1994-1998 & 1999-2003 & 2004-2008 & 2009-2013 \\
\hline Austria & - & - & - & 3.32 & 4.66 & 4.19 & 3.15 & 2.34 & 1.78 \\
\hline Belgium & - & - & - & 3.32 & 4.66 & 4.19 & 3.15 & 2.34 & 1.78 \\
\hline Bulgaria & - & - & - & 3.32 & 4.66 & 4.19 & 3.15 & 2.34 & 1.78 \\
\hline Croatia & - & - & - & - & - & - & 7.77 & 2.46 & 2.39 \\
\hline Cyprus & - & - & - & 3.32 & 4.66 & 4.19 & 3.15 & 2.34 & 1.78 \\
\hline $\begin{array}{l}\text { Czech } \\
\text { Republic }\end{array}$ & - & - & - & 3.32 & 4.66 & 4.19 & 3.15 & 2.34 & 1.78 \\
\hline Denmark & - & - & - & 3.32 & 4.66 & 4.19 & 3.15 & 2.34 & 1.78 \\
\hline Estonia & - & - & - & 3.32 & 4.66 & 4.19 & 3.15 & 2.34 & 1.78 \\
\hline Finland & - & - & - & 3.32 & 4.66 & 4.19 & 3.15 & 2.34 & 1.78 \\
\hline France & - & - & - & 3.32 & 4.66 & 4.19 & 3.15 & 2.34 & 1.78 \\
\hline Germany & - & - & - & 3.32 & 4.66 & 4.19 & 3.15 & 2.34 & 1.78 \\
\hline Greece & - & - & - & 3.32 & 4.66 & 4.19 & 3.15 & 2.34 & 1.78 \\
\hline Hungary & - & - & - & 3.32 & 4.66 & 4.19 & 3.15 & 2.34 & 1.78 \\
\hline Ireland & - & - & - & 3.32 & 4.66 & 4.19 & 3.15 & 2.34 & 1.78 \\
\hline Italy & - & - & - & 3.32 & 4.66 & 4.19 & 3.15 & 2.34 & 1.78 \\
\hline Latvia & - & - & - & 3.32 & 4.66 & 4.19 & 3.15 & 2.34 & 1.78 \\
\hline Lithuania & - & - & - & 3.32 & 4.66 & 4.19 & 3.15 & 2.34 & 1.78 \\
\hline Luxembourg & - & - & - & 3.32 & 4.66 & 4.19 & 3.15 & 2.34 & 1.78 \\
\hline Malta & - & - & - & 3.32 & 4.66 & 4.19 & 3.15 & 2.34 & 1.78 \\
\hline Netherlands & - & - & - & 3.32 & 4.66 & 4.19 & 3.15 & 2.34 & 1.78 \\
\hline Poland & - & - & - & 3.32 & 4.66 & 4.19 & 3.15 & 2.34 & 1.78 \\
\hline Portugal & - & - & - & 3.32 & 4.66 & 4.19 & 3.15 & 2.34 & 1.78 \\
\hline Romania & - & - & - & 3.32 & 4.66 & 4.19 & 3.15 & 2.34 & 1.78 \\
\hline $\begin{array}{l}\text { Slovak } \\
\text { Republic }\end{array}$ & - & - & - & 3.32 & 4.66 & 4.19 & 3.15 & 2.34 & 1.78 \\
\hline
\end{tabular}




\begin{tabular}{|c|c|c|c|c|c|c|c|c|c|}
\hline Slovenia & - & - & - & 3.32 & 4.66 & 4.19 & 3.15 & 2.34 & 1.78 \\
\hline Spain & - & - & - & 3.32 & 4.66 & 4.19 & 3.15 & 2.34 & 1.78 \\
\hline Sweden & - & - & - & 3.32 & 4.66 & 4.19 & 3.15 & 2.34 & 1.78 \\
\hline $\begin{array}{l}\text { United } \\
\text { Kingdom }\end{array}$ & - & - & - & 3.32 & 4.66 & 4.19 & 3.15 & 2.34 & 1.78 \\
\hline Overall & - & - & - & 3.32 & 4.66 & 4.19 & 3.32 & 2.34 & 1.80 \\
\hline
\end{tabular}

Source: Based on World Bank Data (2014).

\subsubsection{Trends in Real Effective Exchange Rates (REER)}

Trends in real effective exchange rates in EU countries don't represent a smooth pattern before integration. Rather, during 1970-1974 the average rate was 101.33 but it declined to 97.02 during 1975-1979. Again it increased to 141.27 during 1980-1984 and reduced to 116.16 during 1985-1989. Continuing the decrease the average rate became 87.74 during 1990-1993. Since then the rate showed an incremental trend from 1994 to 2013. During 1994-1998 it was 89.33, 90.06 during 1999-2003, 99.20 during 2004-2008 and 100.13 during the period of 2009-2013. Gross average of the real effective exchange rate for all twenty eight countries and for forty four years (1970-2013) was 102.47. Before integration, average real effective exchange rate for all countries was 108.70 and after integration it was 94.68. Again, after integration, average real effective exchange rate increased for Austria (by 4.69), Bulgaria (28.70), Croatia (24.00), Czech Republic (33.20), Denmark (6.24), Greece (11.37), Hungary (25.92), Portugal (14.15), Romania (31.15), Slovak Republic (28.23) and United Kingdom (10.62). On the other hand, average rate declined for Belgium (by 2.51), Finland (13.02), France (6.23), Germany (2.16), Italy (0.23), Luxembourg (2.66), Malta (8.27), Netherlands (0.52), Sweden (20.34) and by much greater extent for Poland (418.31) after integration.

Table 7. Trends in real effective exchange rates, in EU, 1970-2013

\begin{tabular}{|c|c|c|c|c|c|c|c|c|c|}
\hline Countries & 1970-1974 & 1975-1979 & 1980-1984 & 1985-1989 & $1990-1993$ & 1994-1998 & 1999-2003 & 2004-2008 & 2009-2013 \\
\hline Austria & - & 91.23 & 94.63 & 99.25 & 101.61 & 104.50 & 97.95 & 101.38 & 100.61 \\
\hline Belgium & - & 107.53 & 99.39 & 97.81 & 100.58 & 101.15 & 93.60 & 99.99 & 100.68 \\
\hline Bulgaria & - & - & - & - & 51.52 & 57.99 & 72.65 & 88.44 & 101.80 \\
\hline Croatia & - & - & - & - & 70.43 & 93.14 & 89.10 & 96.45 & 99.02 \\
\hline Cyprus & - & - & 103.05 & 92.32 & 86.40 & 90.29 & 90.43 & 98.58 & 100.33 \\
\hline $\begin{array}{l}\text { Czech } \\
\text { Republic }\end{array}$ & - & - & - & - & 45.96 & 59.16 & 70.86 & 87.30 & 99.33 \\
\hline Denmark & - & 91.34 & 86.37 & 91.41 & 94.17 & 95.41 & 93.71 & 98.80 & 99.63 \\
\hline Estonia & - & - & - & - & - & - & - & - & - \\
\hline Finland & 101.33 & 111.44 & 117.99 & 126.85 & 120.53 & 106.16 & 100.32 & 102.72 & 100.43 \\
\hline France & - & 110.70 & 106.72 & 104.76 & 104.56 & 104.90 & 96.34 & 101.71 & 99.32 \\
\hline Germany & - & 108.14 & 105.37 & 103.20 & 107.27 & 112.18 & 99.78 & 103.50 & 99.60 \\
\hline Greece & - & 90.44 & 82.93 & 74.51 & 82.31 & 89.07 & 86.48 & 95.26 & 99.01 \\
\hline Hungary & - & - & 61.70 & 55.23 & 60.38 & 67.31 & 77.81 & 96.12 & 98.47 \\
\hline Ireland & - & 84.44 & 93.98 & 101.96 & 100.31 & 93.86 & 87.04 & 104.27 & 100.02 \\
\hline Italy & - & 80.77 & 95.88 & 106.69 & 110.53 & 94.27 & 94.50 & 101.26 & 100.37 \\
\hline Latvia & - & - & - & - & - & - & - & - & - \\
\hline Lithuania & - & - & - & - & - & - & - & - & - \\
\hline Luxembourg & - & 104.02 & 101.37 & 98.78 & 100.07 & 99.16 & 94.11 & 99.35 & 100.53 \\
\hline Malta & - & 101.35 & 114.11 & 103.04 & 89.38 & 87.09 & 90.29 & 99.81 & 100.24 \\
\hline Netherlands & - & 102.26 & 99.63 & 97.27 & 96.03 & 98.13 & 94.53 & 101.03 & 100.02 \\
\hline Poland & - & - & 917.29 & 463.02 & 54.28 & 74.82 & 90.74 & 98.03 & 97.06 \\
\hline Portugal & - & 92.16 & 76.50 & 75.23 & 89.44 & 93.23 & 93.93 & 101.06 & 100.43 \\
\hline Romania & - & - & - & - & 54.74 & 65.01 & 79.14 & 99.66 & 99.72 \\
\hline $\begin{array}{l}\text { Slovak } \\
\text { Republic }\end{array}$ & - & - & - & - & 45.04 & 50.07 & 58.36 & 83.11 & 101.57 \\
\hline Slovenia & - & - & - & - & - & - & - & - & - \\
\hline Spain & - & 77.12 & 83.68 & 88.21 & 101.41 & 89.38 & 88.67 & 98.35 & 100.30 \\
\hline Sweden & - & 118.11 & 132.62 & 127.70 & 135.12 & 117.43 & 105.56 & 105.36 & 102.44 \\
\hline
\end{tabular}




\begin{tabular}{llllllllll}
\hline United & - & 81.30 & 110.86 & 99.84 & 103.59 & 100.11 & 115.52 & 119.34 & 102.11 \\
$\begin{array}{l}\text { Kingdom } \\
\text { Overall }\end{array}$ & $\mathbf{1 0 1 . 3 3}$ & $\mathbf{9 7 . 0 2}$ & $\mathbf{1 4 1 . 2 7}$ & $\mathbf{1 1 6 . 1 6}$ & $\mathbf{8 7 . 7 4}$ & $\mathbf{8 9 . 3 3}$ & $\mathbf{9 0 . 0 6}$ & $\mathbf{9 9 . 2 0}$ & $\mathbf{1 0 0 . 1 3}$ \\
\hline
\end{tabular}

Source: Based on World Bank Data (2014).

\subsubsection{Trends in Inflation Rate}

It can be clearly observed that, average inflation rate increased in each five years period before integration, but it decreased after integration. In fact the rate swelled up from 7.56 percent (1970-1974) to 78.97 percent (1990-1993) and then it reduced to 20.30 percent during 1994-1998. Then it dropped to 4.25 percent during 1999-2003, to 3.57 percent during 2004-2008 and to 2.12 percent during 2009-2013. Gross average rate of inflation for the complete forty four year period for all countries was 18.91 percent, with 27.99 percent before integration and 7.56 percent after integration. Furthermore, before integration, countries that experienced very high rate of average inflation were Bulgaria (67.58 percent), Croatia (564.53), Estonia (89.81), Latvia (176.02), Lithuania (410.24), Poland (55.76), Romania (232.33) and Slovenia (32.86). In addition, after integration, Bulgaria (71.88), Croatia (8.54), Estonia (8.97), Hungary (9.53), Lithuania (9.55), Romania (32.52) experienced high inflation rate.

Table 8. Average inflation rate (\%, in terms of Consumer Prices), in EU, 1970-2013

\begin{tabular}{|c|c|c|c|c|c|c|c|c|c|}
\hline Countries & $1970-1974$ & 1975-1979 & 1980-1984 & 1985-1989 & 1990-1993 & 1994-1998 & $1999-2003$ & 2004-2008 & 2009-2013 \\
\hline Austria & 6.50 & 5.71 & 5.51 & 2.16 & 3.56 & 1.86 & 1.76 & 2.24 & 2.01 \\
\hline Belgium & 6.67 & 7.60 & 7.40 & 2.40 & 2.96 & 1.70 & 1.87 & 2.60 & 1.92 \\
\hline Bulgaria & - & - & - & 3.55 & 131.61 & 271.35 & 5.64 & 7.88 & 2.65 \\
\hline Croatia & - & - & - & 442.26 & 686.81 & 25.23 & 3.17 & 3.51 & 2.26 \\
\hline Cyprus & 7.07 & 6.54 & 8.35 & 3.25 & 5.23 & 3.23 & 2.94 & 2.88 & 1.61 \\
\hline $\begin{array}{l}\text { Czech } \\
\text { Republic }\end{array}$ & - & - & - & - & - & 9.42 & 2.53 & 3.30 & 1.82 \\
\hline Denmark & 8.71 & 9.87 & 9.48 & 4.34 & 2.09 & 2.05 & 2.45 & 1.99 & 1.91 \\
\hline Estonia & - & - & - & - & 89.81 & 23.65 & 3.59 & 5.71 & 2.92 \\
\hline Finland & 8.80 & 12.02 & 9.72 & 4.92 & 3.73 & 1.06 & 1.91 & 1.84 & 1.78 \\
\hline France & 7.67 & 10.14 & 11.20 & 3.57 & 2.77 & 1.45 & 1.58 & 1.97 & 1.31 \\
\hline Germany & - & - & - & - & 4.76 & 1.75 & 1.30 & 1.94 & 1.40 \\
\hline Greece & 10.59 & 14.09 & 21.79 & 17.19 & 17.54 & 7.67 & 3.27 & 3.34 & 1.97 \\
\hline Hungary & 2.59 & 5.33 & 7.17 & 10.74 & 27.15 & 20.62 & 7.78 & 5.64 & 4.10 \\
\hline Ireland & 10.83 & 14.67 & 14.95 & 3.73 & 2.75 & 2.08 & 4.04 & 3.50 & -0.13 \\
\hline Italy & 9.14 & 15.53 & 16.18 & 6.21 & 5.59 & 3.45 & 2.42 & 2.30 & 1.86 \\
\hline Latvia & - & - & - & - & 176.02 & 18.32 & 2.47 & 8.99 & 1.81 \\
\hline Lithuania & - & - & - & - & 410.24 & 30.08 & 0.45 & 4.85 & 2.81 \\
\hline Luxembourg & 6.02 & 6.98 & 7.61 & 1.83 & 3.39 & 1.57 & 2.19 & 2.62 & 2.09 \\
\hline Malta & 4.87 & 6.25 & 6.35 & 0.80 & 2.83 & 3.22 & 2.19 & 2.82 & 2.02 \\
\hline Netherlands & 7.31 & 6.81 & 5.05 & 0.71 & 2.84 & 2.18 & 2.81 & 1.64 & 1.95 \\
\hline Poland & 2.63 & 5.34 & 34.66 & 71.54 & 178.57 & 21.59 & 5.10 & 2.71 & 3.08 \\
\hline Portugal & 11.86 & 22.41 & 22.67 & 12.61 & 9.94 & 3.47 & 3.27 & 2.56 & 1.45 \\
\hline Romania & - & - & - & - & 232.33 & 84.34 & 32.75 & 8.03 & 4.96 \\
\hline $\begin{array}{l}\text { Slovak } \\
\text { Republic }\end{array}$ & - & - & - & - & - & 8.38 & 8.36 & 4.42 & 2.30 \\
\hline Slovenia & - & - & - & - & 32.86 & 12.10 & 7.30 & 3.56 & 1.77 \\
\hline Spain & 9.88 & 18.91 & 13.59 & 6.90 & 5.79 & 3.35 & 3.09 & 3.36 & 1.71 \\
\hline Sweden & 7.41 & 9.74 & 10.26 & 5.61 & 6.68 & 1.12 & 1.60 & 1.57 & 0.89 \\
\hline $\begin{array}{l}\text { United } \\
\text { Kingdom }\end{array}$ & - & - & - & 5.24 & 5.32 & 2.10 & 1.20 & 2.33 & 3.06 \\
\hline Overall & 7.56 & 10.47 & 12.47 & 30.48 & 78.97 & 20.30 & 4.25 & 3.57 & 2.12 \\
\hline
\end{tabular}

Source: Based on World Bank Data (2014). 


\subsection{Impact of Regional Integration on Liberalization and Growth of Non-EU (European) Countries}

\subsubsection{Real GDP Growth}

Over the last forty four years, the Non-EU countries have experienced fluctuating trend in real GDP growth. However, the five years' average figures for real GDP growth shows that it declined from 4.95 percent during 1970-1974 to 1.62 percent during 2009-2013. More specifically, average real GDP growth declined from 4.95 (1970-1974) to 3.63 (1975-1979) percent and to 2.70 (1980-1984). Then it increased to 3.16 (1985-1989) but again dropped significantly to -6.58 (1990-1993). From this point it raised to 3.34 (1994-1998) to 4.41 (1999-2003) and to 6.87 (2004-2008). Afterwards, during 2009-2013 it jumped down to 1.62 percent. From the figure it can be observed that during 1970-1993, average overall GDP growth was 1.57 percent and during 1994-2013 it was 4.06 percent. During the entire period, gross average GDP growth for all twenty one countries was 2.68 percent, for Andorra it was 3.80 percent, for Azerbaijan 5.16 percent, for Bosnia and Herzegovina 11.41 percent, Ireland 3.53 percent, Liechtenstein 3.79 percent, San Marino 3.73 percent and for Turkey it was 4.31 percent. This trend is somewhat contrasting in compare to the EU countries. It is obvious that smaller economies of EU are clearly benefitting from the integration whereas smaller non-EU countries are not been able to get that advantage. The picture of real GDP clearly signifies that notion.

Table 9. Average GDP growth rates (\%), in Non-EU 1970-2013

\begin{tabular}{|c|c|c|c|c|c|c|c|c|c|}
\hline Countries & 1970-1974 & 1975-1979 & 1980-1984 & 1985-1989 & $1990-1993$ & 1994-1998 & $1999-2003$ & 2004-2008 & 2009-2013 \\
\hline Albania & - & - & 2.14 & 3.01 & -9.19 & 6.64 & 6.60 & 6.00 & 2.48 \\
\hline Andorra & 6.55 & 1.64 & 1.38 & 4.21 & 1.56 & 4.41 & 5.93 & 4.84 & - \\
\hline Armenia & - & - & - & - & -20.77 & 5.76 & 9.20 & 11.64 & 0.69 \\
\hline Azerbaijan & - & - & - & - & -15.47 & -2.88 & 10.04 & 21.38 & 4.47 \\
\hline Belarus & - & - & - & - & -6.13 & 0.10 & 5.20 & 9.96 & 3.21 \\
\hline $\begin{array}{l}\text { Bosnia and } \\
\text { Herzegovina }\end{array}$ & - & - & - & - & - & 39.94 & 5.76 & 5.91 & -0.25 \\
\hline Georgia & 6.53 & 7.03 & 4.31 & -0.72 & -27.52 & 3.40 & 5.21 & 7.90 & 3.76 \\
\hline Iceland & 7.84 & 5.26 & 2.83 & 3.66 & -0.28 & 3.95 & 2.98 & 5.39 & -0.66 \\
\hline Kazakhstan & - & - & - & - & -8.50 & -4.10 & 9.02 & 8.44 & 5.40 \\
\hline Liechtenstein & 1.67 & 4.14 & 2.56 & 6.08 & 3.00 & 6.93 & 1.99 & 4.33 & -1.16 \\
\hline $\begin{array}{l}\text { Macedonia, } \\
\text { FYR }\end{array}$ & - & - & - & - & -6.74 & 0.63 & 1.61 & 5.02 & 1.50 \\
\hline Moldova & - & - & 4.68 & 2.11 & -12.17 & -8.48 & 3.84 & 6.11 & 3.22 \\
\hline Monaco & 5.23 & 2.90 & 1.54 & 3.08 & 1.03 & 2.24 & 2.30 & 6.80 & - \\
\hline Montenegro & - & - & - & - & - & 4.90 & -0.16 & 6.96 & 0.21 \\
\hline Norway & 4.24 & 4.63 & 3.19 & 2.40 & 2.84 & 4.48 & 1.95 & 2.31 & 0.75 \\
\hline $\begin{array}{l}\text { Russian } \\
\text { Federation }\end{array}$ & - & - & - & - & -7.81 & -4.84 & 6.71 & 7.10 & 1.14 \\
\hline San Marino & 4.53 & 3.36 & 1.82 & 3.29 & 3.28 & 6.21 & 4.21 & 3.24 & - \\
\hline Serbia & - & - & - & - & -18.86 & 5.44 & 1.25 & 5.50 & 0.00 \\
\hline Switzerland & 2.95 & -0.67 & 1.71 & 2.95 & 0.65 & 1.40 & 1.30 & 2.98 & 1.16 \\
\hline Turkey & 5.02 & 4.38 & 3.53 & 4.67 & 5.67 & 4.10 & 1.83 & 6.00 & 3.86 \\
\hline Ukraine & - & - & - & 3.22 & -9.67 & -10.01 & 5.90 & 6.46 & -0.66 \\
\hline Overall & 4.95 & 3.63 & 2.70 & 3.16 & -6.58 & 3.34 & 4.41 & 6.87 & 1.62 \\
\hline
\end{tabular}

Source: Based on World Bank Data (2014).

\subsubsection{Trends in Import Orientation Ratio}

Import orientation ratio also showed an instable trend for Non-EU countries during the last forty four years. During this entire period import orientation has grown around 64.45 percent for Non-EU countries. From 1970 to 1993 the growth rate was around 40.85 percent but from 1994 to 2013 it was only 8.92 percent. The average of the import orientation ratio for Non-EU countries from 1970-1993 was 31.74 percent and from 1994-2013 the average was 48.02 percent. The five years' averages for all Non-EU countries were 29.62 (1970-1974), 29.11 (1975-1979), 28.96 (1980-1984), 29.76 (1985-1989), 41.23 (1990-1993), 44.72 (1994-1998), 47.18 (1999-2003), 51.48 (2004-2008) and 48.71 percent (2009-2013). For the total period, average import orientation ratios for 
Armenia (50.72), Belarus (65.17), Bosnia and Herzegovina (74.01), Georgia (50.39), Macedonia, FYR (57.24), Moldova (71.74), Montenegro (66.17) and Ukraine (46.35) were comparatively higher than other Non-EU countries. Again the result of the import penetration ratio is dissimilar to those of EU countries. It was expected that non-EU countries are less liberal in international trade in compare to EU countries simply because they are not in such common platform by engaged themselves in regional integration.

Table 10. Average import orientation (\% of GDP), in Non-EU, 1970-2013

\begin{tabular}{|c|c|c|c|c|c|c|c|c|c|}
\hline Countries & 1970-1974 & 1975-1979 & 1980-1984 & 1985-1989 & 1990-1993 & 1994-1998 & 1999-2003 & 2004-2008 & 2009-2013 \\
\hline Albania & - & - & 21.66 & 17.88 & 50.40 & 35.96 & 40.16 & 50.04 & 53.60 \\
\hline Andorra & - & - & - & - & - & - & - & - & - \\
\hline Armenia & - & - & - & - & 57.12 & 60.48 & 48.62 & 41.52 & 47.12 \\
\hline Azerbaijan & - & - & - & - & 52.76 & 47.05 & 46.63 & 43.27 & 24.08 \\
\hline Belarus & - & - & - & - & 54.57 & 63.63 & 68.14 & 66.69 & 70.70 \\
\hline $\begin{array}{l}\text { Bosnia and } \\
\text { Herzegovina }\end{array}$ & - & - & - & - & - & 82.58 & 79.94 & 74.55 & 55.22 \\
\hline Georgia & - & - & - & 44.03 & 53.69 & 52.62 & 41.09 & 54.62 & 54.41 \\
\hline Iceland & 40.52 & 35.96 & 36.80 & 34.80 & 31.21 & 34.61 & 38.44 & 45.33 & 48.93 \\
\hline Kazakhstan & - & - & - & - & 61.04 & 39.79 & 45.25 & 41.80 & 29.74 \\
\hline Liechtenstein & - & - & - & - & - & - & - & - & - \\
\hline $\begin{array}{l}\text { Macedonia, } \\
\text { FYR }\end{array}$ & - & - & - & - & 42.45 & 47.33 & 56.99 & 66.53 & 69.93 \\
\hline Moldova & - & - & - & - & 38.72 & 65.06 & 76.31 & 91.26 & 80.74 \\
\hline Monaco & - & - & - & - & - & - & - & - & - \\
\hline Montenegro & - & - & - & - & - & - & 54.99 & 75.99 & 65.29 \\
\hline Norway & 38.10 & 40.85 & 35.50 & 35.16 & 32.12 & 32.93 & 29.09 & 28.87 & 28.06 \\
\hline $\begin{array}{l}\text { Russian } \\
\text { Federation }\end{array}$ & - & - & - & 21.01 & 27.42 & 23.60 & 24.55 & 21.66 & 21.62 \\
\hline San Marino & - & - & - & - & - & - & - & - & - \\
\hline Serbia & - & - & - & - & - & 27.53 & 37.94 & 52.21 & 52.83 \\
\hline Switzerland & 31.17 & 30.46 & 35.65 & 35.43 & 32.78 & 32.81 & 38.08 & 41.92 & 40.99 \\
\hline Turkey & 8.70 & 9.15 & 15.22 & 17.63 & 17.73 & 24.63 & 22.66 & 26.99 & 29.51 \\
\hline Ukraine & - & - & - & 32.14 & 25.21 & 44.95 & 53.08 & 51.82 & 55.33 \\
\hline Overall & 29.62 & 29.11 & 28.96 & 29.76 & 41.23 & 44.72 & 47.18 & 51.48 & 48.71 \\
\hline
\end{tabular}

Source: Based on World Bank Data (2014).

\subsubsection{Trends in Import Penetration Ratio}

Again a variable trend for import penetration ratio has been found for the Non-EU countries over the period of 1970-2013. The overall ratio of import penetration was highest during the period of 2004-2008 (45.71 percent). However, the overall average ratio for all the twenty one Non-EU countries for the forty four years period was 36.11 percent while this ratio during 1970-1993 was 30.67 percent and during 1994-2013, it was 42.91 percent. The growth of this ratio for the entire period was 53.43 percent. Unlike the absolute average figure, the growth rate was lower during 1994-2013 (14.65 percent) than the growth rate during 1970-1993 (34.55 percent). Overall averages for the twenty one countries were 29.03 (1970-1974), 28.67 (1975-1979), 28.78 (1980-1984), 27.81 (1985-1989), 39.06 (1990-1993), 38.85 (1994-1998), 42.53 (1999-2003), 45.71 (2004-2008) and 44.54 percent (2009-2013). Belarus had highest import penetration ratio (62.28) among all the Non-EU countries on an average. Besides, Armenia (40.96), Azerbaijan (44.33), Georgia (42.18), Kazakhstan (43.17), Macedonia, FYR (49.56), Moldova (55.88), Montenegro (52.08) and Ukraine (45.84) higher import penetration ratio than other Non-EU countries. The import penetration ratio for the Non-EU countries is less than those of EU countries declare clear impact of integration. 
Table 11. Average import penetration (\% of Total Consumption), in Non-EU, 1970-2013

\begin{tabular}{|c|c|c|c|c|c|c|c|c|c|}
\hline Countries & $1970-1974$ & $1975-1979$ & 1980-1984 & 1985-1989 & $1990-1993$ & 1994-1998 & $1999-2003$ & 2004-2008 & 2009-2013 \\
\hline Albania & - & - & 19.00 & 17.57 & 34.19 & 28.87 & 33.19 & 40.12 & 44.39 \\
\hline Andorra & - & - & - & - & - & - & - & - & - \\
\hline Armenia & - & - & - & - & 48.98 & 44.70 & 39.75 & 35.17 & 37.78 \\
\hline Azerbaijan & - & - & - & - & 57.05 & 38.73 & 42.77 & 51.80 & 33.82 \\
\hline Belarus & - & - & - & - & 52.50 & 59.56 & 65.92 & 63.59 & 67.89 \\
\hline $\begin{array}{l}\text { Bosnia and } \\
\text { Herzegovina }\end{array}$ & - & - & - & - & - & 51.58 & 52.45 & 54.22 & - \\
\hline Georgia & - & - & - & - & 45.37 & 39.92 & 35.59 & 44.35 & 46.29 \\
\hline Iceland & 39.14 & 35.58 & 36.53 & 35.11 & 31.46 & 34.93 & 37.35 & 41.26 & 53.22 \\
\hline Kazakhstan & - & - & - & - & 58.64 & 38.01 & 46.63 & 46.94 & 34.91 \\
\hline Liechtenstein & - & - & - & - & - & - & - & - & - \\
\hline $\begin{array}{l}\text { Macedonia, } \\
\text { FYR }\end{array}$ & - & - & - & - & 40.57 & 42.28 & 49.52 & 55.51 & 58.12 \\
\hline Moldova & - & - & - & - & 37.55 & 55.76 & 61.08 & 63.30 & 58.06 \\
\hline Monaco & - & - & - & - & - & - & - & - & - \\
\hline Montenegro & - & - & - & - & - & - & 45.84 & 57.18 & 51.97 \\
\hline Norway & 37.66 & 39.16 & 38.18 & 35.54 & 34.48 & 35.11 & 33.66 & 34.20 & 32.03 \\
\hline $\begin{array}{l}\text { Russian } \\
\text { Federation }\end{array}$ & - & - & - & 21.20 & 30.05 & 24.65 & 28.74 & 24.43 & 23.36 \\
\hline San Marino & - & - & - & - & - & - & - & - & - \\
\hline Serbia & - & - & - & - & - & 25.64 & 32.32 & 42.09 & - \\
\hline Switzerland & 30.90 & 31.24 & 35.60 & 35.82 & 33.63 & 34.28 & 40.26 & 45.87 & 45.84 \\
\hline Turkey & 8.43 & 8.68 & 14.57 & 17.34 & 17.05 & 23.84 & 22.76 & 25.91 & 27.95 \\
\hline Ukraine & - & - & - & 32.12 & 25.36 & 43.71 & 55.18 & 51.16 & 52.42 \\
\hline Overall & 29.03 & 28.67 & 28.78 & 27.81 & 39.06 & 38.85 & 42.53 & 45.71 & 44.54 \\
\hline
\end{tabular}

Source: Based on World Bank Data (2014).

\subsubsection{Trends in Export Orientation Ratio}

Average of the export orientation ratios for Non-EU countries followed a fluctuating pattern for the whole period of forty four years. The rate of increments from each five year period to next were $-0.95,6.54,0.76,27.14$, $-15.45,16.21,10.74$ and 1.46percent starting from 1970-1970 to 2009-2013. Average growth rate for the whole period was 49.24percent. Again, growth during 1970-1993 was 35.19percent and during 1994-2013 was 30.56percent. Therefore, it is clear that, export orientation ratio has grown slower in the later period. But, Albania, Belarus, Iceland, Macedonia FYR, Moldova, Norway, Russian Federation, Switzerland, Turkey and Ukraine had higher average export orientation ratios during 1994-2013 than they had during 1970-1993. Moreover, Azerbaijan (47.36), Belarus (60.75), Kazakhstan (46.15), Macedonia FYR (42.47), Moldova (45.37) and Ukraine (45.25) had impressive average export orientation ratio for the entire period. Average of the ratios for each of the five years periods were 27.48 (1970-1974), 27.22 (1975-1979), 29.00 (1980-1984), 29.22 (1985-1989), 37.15 (1990-1993), 31.41 (1994-1998), 36.50 (1999-2003), 40.42 (2004-2008) and 41.01 percent (2009-2013). Gross average for the entire period was 33.27 percent. During 1970-1993 the average was 30.01 percent and during 1994-2013 it was 37.34 percent.

Table 12. Average export orientation ratio (\% of GDP), in Non-EU, 1970-2013

\begin{tabular}{|c|c|c|c|c|c|c|c|c|c|}
\hline Countries & 1970-1974 & 1975-1979 & 1980-1984 & 1985-1989 & $1990-1993$ & 1994-1998 & 1999-2003 & 2004-2008 & 2009-2013 \\
\hline Albania & - & - & 20.22 & 16.22 & 12.25 & 11.48 & 19.60 & 25.46 & 32.84 \\
\hline Andorra & - & - & - & - & - & - & - & - & - \\
\hline Armenia & - & - & - & - & 40.70 & 25.15 & 26.22 & 23.23 & 22.33 \\
\hline Azerbaijan & - & - & - & - & 58.29 & 26.77 & 38.55 & 62.43 & 52.96 \\
\hline Belarus & - & - & - & - & 52.43 & 57.24 & 64.79 & 61.93 & 65.69 \\
\hline $\begin{array}{l}\text { Bosnia and } \\
\text { Herzegovina }\end{array}$ & - & - & - & - & - & 22.92 & 27.87 & 37.09 & 32.41 \\
\hline Georgia & - & - & - & 42.16 & 37.57 & 25.73 & 25.52 & 31.60 & 36.76 \\
\hline
\end{tabular}




\begin{tabular}{|c|c|c|c|c|c|c|c|c|c|}
\hline Iceland & 36.88 & 35.04 & 36.00 & 35.68 & 32.01 & 35.71 & 35.54 & 35.42 & 57.05 \\
\hline Kazakhstan & - & - & - & - & 55.95 & 35.31 & 48.07 & 52.78 & 44.52 \\
\hline Liechtenstein & - & - & - & - & - & - & - & - & - \\
\hline $\begin{array}{l}\text { Macedonia, } \\
\text { FYR }\end{array}$ & - & - & - & - & 37.46 & 35.58 & 41.92 & 46.79 & 49.59 \\
\hline Moldova & - & - & - & - & 35.18 & 49.23 & 51.59 & 47.08 & 41.73 \\
\hline Monaco & - & - & - & - & - & - & - & - & - \\
\hline Montenegro & - & - & - & - & - & - & 35.30 & 43.96 & 39.49 \\
\hline Norway & 36.99 & 36.70 & 42.55 & 36.08 & 38.97 & 39.17 & 42.63 & 44.43 & 40.45 \\
\hline $\begin{array}{l}\text { Russian } \\
\text { Federation }\end{array}$ & - & - & - & 21.90 & 32.99 & 27.81 & 38.93 & 32.97 & 29.08 \\
\hline San Marino & - & - & - & - & - & - & - & - & - \\
\hline Serbia & - & - & - & - & - & 20.15 & 20.91 & 28.23 & 35.57 \\
\hline Switzerland & 30.32 & 33.03 & 35.55 & 36.54 & 35.36 & 37.09 & 43.50 & 50.42 & 51.56 \\
\hline Turkey & 5.71 & 4.09 & 10.67 & 15.92 & 13.82 & 21.74 & 23.04 & 22.86 & 24.10 \\
\hline Ukraine & - & - & - & 32.08 & 25.90 & 42.12 & 56.89 & 50.22 & 49.87 \\
\hline Overall & 27.48 & 27.22 & 29.00 & 29.22 & 37.15 & 31.41 & 36.50 & 40.42 & 41.01 \\
\hline
\end{tabular}

Source: Based on World Bank Data (2014).

\subsubsection{Trends in Ratio of Trade Share}

The overall average ratios for all twenty one Non-EU countries were 75.52 percent and the growth rate was 58.04 percent (1970-2013). Absolute average during 1970-1993 was 61.66 percent and the growth was 35.87 percent. During 1994-2013 average ratio of trade share was 86.10 percent and the growth rate was 17.50 percent. Five years averages for all EU countries along with period to period growth rates were 57.10, $56.32(-1.37)$, 57.96 (1.64), 59.33 (2.36), 77.58 (30.76), 76.80 (-1.01), 84.87 (10.51), 92.47 (8.95), 90.24 (-2.41) percent. Belarus had the highest (125.92) and some other countries like Azerbaijan (89.70), Bosnia and Herzegovina (103.97), Georgia (82.79), Kazakhstan (87.29), Macedonia FYR (99.70), Moldova (117.11), Montenegro (106.06) and Ukraine (91.60) had higher share of GDP as trade than others for the whole period.

Table 13. Average ratio of trade share (\% of GDP), in Non-EU, 1970-2013

\begin{tabular}{|c|c|c|c|c|c|c|c|c|c|}
\hline Countries & $1970-1974$ & 1975-1979 & 1980-1984 & 1985-1989 & $1990-1993$ & $\begin{array}{l}1994-1998 \\
\end{array}$ & 1999-2003 & 2004-2008 & $2009-2013$ \\
\hline Albania & - & - & 41.87 & 34.10 & 62.65 & 47.44 & 59.76 & 75.50 & 86.45 \\
\hline Andorra & - & - & - & - & - & - & - & - & - \\
\hline Armenia & - & - & - & - & 97.81 & 85.63 & 74.85 & 64.74 & 69.45 \\
\hline Azerbaijan & - & - & - & - & 111.04 & 73.82 & 85.18 & 105.70 & 77.04 \\
\hline Belarus & - & - & - & - & 107.00 & 120.87 & 132.93 & 128.61 & 136.39 \\
\hline $\begin{array}{l}\text { Bosnia and } \\
\text { Herzegovina }\end{array}$ & - & - & - & - & - & 105.50 & 107.81 & 111.64 & 87.64 \\
\hline Georgia & - & - & - & 86.18 & 91.26 & 78.35 & 66.61 & 86.22 & 91.17 \\
\hline Iceland & 77.40 & 71.00 & 72.80 & 70.49 & 63.22 & 70.32 & 73.98 & 80.74 & 105.97 \\
\hline Kazakhstan & - & - & - & - & 116.99 & 75.11 & 93.32 & 94.58 & 74.26 \\
\hline Liechtenstein & - & - & - & - & - & - & - & - & - \\
\hline $\begin{array}{l}\text { Macedonia, } \\
\text { FYR }\end{array}$ & - & - & - & - & 79.90 & 82.91 & 98.91 & 113.32 & 119.52 \\
\hline Moldova & - & - & - & - & 73.90 & 114.30 & 127.90 & 138.34 & 122.47 \\
\hline Monaco & - & - & - & - & - & - & - & - & - \\
\hline Montenegro & - & - & - & - & - & - & 90.30 & 119.96 & 104.78 \\
\hline Norway & 75.09 & 77.56 & 78.05 & 71.25 & 71.09 & 72.10 & 71.72 & 73.30 & 68.51 \\
\hline $\begin{array}{l}\text { Russian } \\
\text { Federation }\end{array}$ & - & - & - & 42.91 & 60.41 & 51.42 & 63.49 & 54.62 & 50.70 \\
\hline San Marino & - & - & - & - & - & - & - & - & - \\
\hline Serbia & - & - & - & - & - & 47.68 & 58.85 & 80.44 & 88.40 \\
\hline Switzerland & 61.49 & 63.48 & 71.20 & 71.97 & 68.14 & 69.90 & 81.58 & 92.34 & 92.56 \\
\hline Turkey & 14.41 & 13.25 & 25.88 & 33.55 & 31.54 & 46.37 & 45.70 & 49.85 & 53.62 \\
\hline Ukraine & - & - & - & 64.22 & 51.12 & 87.06 & 109.97 & 102.03 & 105.20 \\
\hline Overall & 57.10 & 56.32 & $\mathbf{5 7 . 9 6}$ & 59.33 & 77.58 & 76.80 & 84.87 & 92.47 & 90.24 \\
\hline
\end{tabular}

Source: Based on World Bank Data (2014). 


\subsubsection{Trends in Collected Tariff Ratios}

Average tariff collection ratio as a percentage of import was highest during 1994-1998 (8.79 percent) within the total period from 1985-2013. Data were unavailable from 1970 to 1984. From 1985 to 2013 this ratio for each of the five years period were 2.10 (1985-1989), 5.68 (1990-1993), 8.79 (1994-1998), 7.20 (1999-2003), 5.29 (2004-2008) and 3.88 (2009-2013). But, for the total period (1985-2013), average tariff collection ratio for all countries was 5.49. Another aspect can be noticed that, though tariff collection ratio increased from the period of 1985-1989 to the period of 1990-1993. Afterwards, it continuously declined (by 55.86 percent from 1994 to 2013). During the whole period, Russian Federation had the highest tariff collection ratio of 9.52 percent. In addition to this country, Albania (6.75), Azerbaijan (8.98), Belarus (9.02), Kazakhstan (5.96), Macedonia, FYR (5.86), Serbia (9.09) and Ukraine (5.59) had also higher average tariff collection ratio as a percentage of import.

Table 14. Average tariff collection ratio (\% of Total Imports), in Non-EU, 1970-2013

\begin{tabular}{|c|c|c|c|c|c|c|c|c|c|}
\hline Countries & $1970-1974$ & 1975-1979 & 1980-1984 & 1985-1989 & $1990-1993$ & 1994-1998 & $1999-2003$ & 2004-2008 & 2009-2013 \\
\hline Albania & - & - & - & - & - & 16.85 & 9.98 & 4.79 & 3.20 \\
\hline Andorra & - & - & - & - & - & - & - & - & - \\
\hline Armenia & - & - & - & - & - & - & 3.26 & 3.64 & 4.65 \\
\hline Azerbaijan & - & - & - & - & - & - & 10.38 & 9.23 & 8.26 \\
\hline Belarus & - & - & - & - & - & 12.40 & 11.30 & 8.00 & 7.02 \\
\hline $\begin{array}{l}\text { Bosnia and } \\
\text { Herzegovina }\end{array}$ & - & - & - & - & - & - & 5.31 & 7.05 & 3.36 \\
\hline Georgia & - & - & - & - & - & - & 9.18 & 3.57 & 0.84 \\
\hline Iceland & - & - & - & - & 3.60 & 5.29 & 5.73 & 3.68 & 1.99 \\
\hline Kazakhstan & - & - & - & - & - & 9.85 & - & 3.38 & 6.37 \\
\hline Liechtenstein & - & - & - & - & - & - & - & - & - \\
\hline $\begin{array}{l}\text { Macedonia, } \\
\text { FYR }\end{array}$ & - & - & - & - & - & - & 10.13 & 6.80 & 3.61 \\
\hline Moldova & - & - & - & - & - & 5.75 & 5.03 & 4.26 & 4.57 \\
\hline Monaco & - & - & - & - & - & - & - & - & - \\
\hline Montenegro & - & - & - & - & - & - & - & 3.80 & 2.76 \\
\hline Norway & - & - & - & 2.1 & 2.86 & 4.66 & 2.36 & 3.43 & 0.91 \\
\hline $\begin{array}{l}\text { Russian } \\
\text { Federation }\end{array}$ & - & - & - & - & 8.34 & 12.09 & 10.57 & 9.81 & 7.15 \\
\hline San Marino & - & - & - & - & - & - & - & - & - \\
\hline Serbia & - & - & - & - & - & - & 9.59 & 8.09 & - \\
\hline Switzerland & - & - & - & - & 6.27 & 5.34 & 2.72 & 3.15 & 0.61 \\
\hline Turkey & - & - & - & - & 7.35 & 7.71 & 4.92 & 2.29 & 2.47 \\
\hline Ukraine & - & - & - & - & - & 7.93 & 7.60 & 4.94 & 4.24 \\
\hline Overall & - & - & - & 2.10 & 5.68 & 8.79 & 7.20 & 5.29 & 3.88 \\
\hline
\end{tabular}

Source: Based on World Bank Data (2014).

\subsubsection{Trends in Real Effective Exchange Rates (REER)}

Trends in real effective exchange rates in Non-EU countries represent an increasing trend from 1975 to 1993 but after that it fluctuated from period to period up to 2013. Specifically, during 1975-1979 the average rate was 94.55 percent which increased to 107.71 during $1980-1984$ to 109.65 during 1985-1989. It also increased to 110.41 during 1990-1993 but then it declined to 91.23 during 1994-1998. It declined further to 88.03 during 1999-2003 but increased in the next two periods (98.29 during 2004-2008 and 101.83 during 2009-2013). Gross average of the real effective exchange rate for all twenty one countries and for the whole period (1975-2013) was 100.21. During 1975-1993, average real effective exchange rate for all countries was 105.58 and during 1994-2013 it was 94.85. For the period of 1970-1993, effective real exchange rate for Iceland was 131.05, for Macedonia, FYR 132.22, for Norway 95.85, for Switzerland 89.18 and for Ukraine it was 94.91. But for the period of 1994-2013, rate for Armenia was 80.16, Georgia 87.42, Iceland 122.89, Macedonia, FYR 104.71, Moldova 85.20, Norway 95.03, Russian federation 78.38, Switzerland 96.08 and for Ukraine the real effective exchange rate was 103.73 . 
Table 15. Trends in real effective exchange rates, in Non-EU, 1970-2013

\begin{tabular}{|c|c|c|c|c|c|c|c|c|c|}
\hline Countries & 1970-1974 & 1975-1979 & 1980-1984 & 1985-1989 & $1990-1993$ & 1994-1998 & $1999-2003$ & 2004-2008 & 2009-2013 \\
\hline Albania & - & - & - & - & - & - & - & - & - \\
\hline Andorra & - & - & - & - & - & - & - & - & - \\
\hline Armenia & - & - & - & - & - & 60.40 & 72.47 & 88.21 & 99.56 \\
\hline Azerbaijan & - & - & - & - & - & - & - & - & - \\
\hline Belarus & - & - & - & - & - & - & - & - & - \\
\hline $\begin{array}{l}\text { Bosnia and } \\
\text { Herzegovina }\end{array}$ & - & - & - & - & - & - & - & - & - \\
\hline Georgia & - & - & - & - & - & 73.57 & 79.35 & 90.50 & 106.28 \\
\hline Iceland & - & 103.71 & 138.68 & 140.57 & 136.96 & 123.85 & 127.18 & 139.72 & 100.82 \\
\hline Kazakhstan & - & - & - & - & - & - & - & - & - \\
\hline Liechtenstein & - & - & - & - & - & - & - & - & - \\
\hline $\begin{array}{l}\text { Macedonia, } \\
\text { FYR }\end{array}$ & - & - & - & - & 132.22 & 117.64 & 100.65 & 100.84 & 99.72 \\
\hline Moldova & - & - & - & - & - & 79.76 & 69.44 & 85.61 & 105.98 \\
\hline Monaco & - & - & - & - & - & - & - & - & - \\
\hline Montenegro & - & - & - & - & - & - & - & - & - \\
\hline Norway & - & 90.92 & 98.26 & 98.57 & 95.60 & 91.56 & 92.83 & 96.74 & 98.99 \\
\hline $\begin{array}{l}\text { Russian } \\
\text { Federation }\end{array}$ & - & - & - & - & - & 66.66 & 58.80 & 85.84 & 102.20 \\
\hline San Marino & - & - & - & - & - & - & - & - & - \\
\hline Serbia & - & - & - & - & - & - & - & - & - \\
\hline Switzerland & - & 89.03 & 86.19 & 89.82 & 92.33 & 97.50 & 92.59 & 91.21 & 103.04 \\
\hline Turkey & - & - & - & - & - & - & - & - & - \\
\hline Ukraine & - & - & - & - & 94.91 & 110.11 & 98.96 & 105.99 & 99.88 \\
\hline Overall & - & 94.55 & 107.71 & 109.65 & 110.41 & 91.23 & 88.03 & 98.29 & 101.83 \\
\hline
\end{tabular}

Source: Based on World Bank Data (2014).

\subsubsection{Trends in Inflation Rate}

From the average inflation rate for Non-EU countries from 1970 to 2013, it can be clearly observed that, average inflation rate increased from period to period up to 1993, but it decreased afterwards. In fact the rate swelled up from 11.75 percent (1970-1974) to 843.86 percent (1990-1993) and then it reduced to 190.05 percent during 1994-1998. Then it dropped to 20.71 percent during 1999-2003, to 7.47 percent during 2004-2008 and to 5.77 percent during 2009-2013. Gross average rate of inflation for the complete forty four year period for all countries was 128 percent, with 185.60 percent during 1970-1993 and 56 percent during 1994-2013. Furthermore, countries that experienced very high rate of average inflation during the complete period were Armenia (182.55), Azerbaijan (149.89), Belarus (243.56), Kazakhstan (112.20), Russian Federation (82.02) and Ukraine (299.13).

Table 16. Average inflation rate (\%, in terms of Consumer Prices), in Non-EU, 1970-2013

\begin{tabular}{|c|c|c|c|c|c|c|c|c|c|}
\hline Countries & $1970-1974$ & $1975-1979$ & 1980-1984 & 1985-1989 & $1990-1993$ & 1994-1998 & 1999-2003 & 2004-2008 & $2009-2013$ \\
\hline Albania & - & - & - & - & 155.51 & 19.38 & 2.36 & 2.66 & 2.65 \\
\hline Andorra & - & - & - & - & - & - & - & - & - \\
\hline Armenia & - & - & - & - & - & 718.15 & 1.76 & 4.77 & 5.52 \\
\hline Azerbaijan & - & - & - & - & 558.60 & 419.33 & -0.03 & 12.44 & 4.31 \\
\hline Belarus & - & - & - & - & 1190.23 & 623.98 & 118.87 & 11.75 & 30.29 \\
\hline $\begin{array}{l}\text { Bosnia and } \\
\text { Herzegovina }\end{array}$ & - & - & - & - & - & - & - & 5.02 & 1.49 \\
\hline Georgia & - & - & - & - & - & 53.18 & 7.65 & 8.46 & 3.19 \\
\hline Iceland & 18.64 & 40.46 & 54.76 & 23.57 & 7.59 & 1.79 & 4.40 & 6.31 & 6.09 \\
\hline Kazakhstan & - & - & - & - & - & 423.45 & 8.42 & 10.19 & 6.74 \\
\hline Liechtenstein & - & - & - & - & - & - & - & - & - \\
\hline $\begin{array}{l}\text { Macedonia, } \\
\text { FYR }\end{array}$ & - & - & - & - & - & 29.45 & 2.79 & 2.98 & 2.16 \\
\hline
\end{tabular}




\begin{tabular}{|c|c|c|c|c|c|c|c|c|c|}
\hline Moldova & - & - & - & - & - & 18.24 & 19.37 & 12.43 & 4.84 \\
\hline Monaco & - & - & - & - & - & - & - & - & - \\
\hline Montenegro & - & - & - & - & - & - & - & 5.34 & 2.59 \\
\hline Norway & 8.18 & 8.57 & 10.12 & 6.57 & 3.04 & 1.99 & 2.44 & 1.76 & 1.74 \\
\hline $\begin{array}{l}\text { Russian } \\
\text { Federation }\end{array}$ & - & - & - & - & 874.62 & 119.06 & 31.49 & 11.27 & 7.76 \\
\hline San Marino & - & - & - & - & - & - & - & 2.40 & 2.24 \\
\hline Serbia & - & - & - & - & - & 57.93 & 47.59 & 11.53 & 8.08 \\
\hline Switzerland & 7.07 & 2.88 & 4.41 & 2.13 & 4.64 & 0.80 & 0.93 & 1.24 & -0.09 \\
\hline Turkey & 13.12 & 33.52 & 51.47 & 51.07 & 65.61 & 89.02 & 48.89 & 9.90 & 7.53 \\
\hline Ukraine & - & - & - & - & 4734.91 & 274.96 & 13.76 & 13.95 & 6.70 \\
\hline Overall & 11.75 & 21.36 & 30.19 & 20.84 & 843.86 & 190.05 & 20.71 & 7.47 & 5.77 \\
\hline
\end{tabular}

Source: Based on World Bank Data (2014).

\section{Conclusion}

Regional integration and its impact on trade liberalization and growth is one of the highly debated and discussed issues of modern theories and practices of economics and international trade. We have investigated the relationship among those important variables by investigating perhaps the most effective, organized and structured integration of the planet which is the EU. In order to reveal the exact picture and also drawing perfect comparative picture we have analyzed both EU and Non-EU countries of Europe. Evidence drawn on the basis of empirical secondary yet quantitative data through the trend and ratio analysis of eight key variables developed from the literature. Those trend and ratio analysis was evaluated by using data of last forty years or so. We have investigated the data for the two periods of before and after integration. In-depth analysis reveals that EU countries experience steady performances both in trade liberalization and also in growth. However, there are not vast changes between the periods of before and after integration. While this in shorter sight seems to represent somewhat less impact of integration but this also explores areas for further analysis. Most of those EU economies barring Germany, France, UK and The Netherlands are not so diversified in nature. Therefore, this growth rate was supposed to be declined. They are been able to make it steadier due to coming in the common platform of trade integration. The trade liberalization performance of EU countries also got better after the integration and performed well above Non-EU countries. The growth rate and trade liberalization performance of Non-EU countries are below par and also volatile in nature in compare to those of EU countries. While it cannot be said that such poor performance is mainly because their unwillingness and sometimes inabilities to come into the integration but they are lagging behind the EU countries. EU countries are definitely enjoying comparative advantages due to their participation in EU. Future researches in this area can explore the impact of regional integration in other parts of the world (mentioned in the literature). Also some extensive works can be done by drawing comparative analysis among regional integrations in the world and also on their modes and structures. For example works can be taken place between ASEAN and EU and their structure and effectiveness.

\section{Reference}

Acemoglu, D. (2008). Introduction to Modern Economic Growth. New Jersey: Princeton University Press.

Adelman, I. (1961). Theories of Economic Growth and Development. California: Stanford University Press.

Ades, A., Glaeser, E., (1999) Evidence on Growth, Increasing Returns, and the Extent of the Market. Quarterly Journal of Economics, 104, 1025-1045.

African Union. (2014). The Official Website of African Union. Retrieved from http://www.au.int/en/

Arab League Online. (2014). The Official Website of Arab League Online. Retrieved from http://www.arableagueonline.org/

Artelaris, P., Arvanitidis, P., \& Petrakos, G. (2007). Theoretical and methodological study on dynamic growth regions and factors explaining their growth performance. Paper presented at the 2nd Workshop of DYNREG in Athens.

Association of Southeast Asian Nations. (2014). The Official Website of Association of Southeast Asian Nations. Retrieved from http://www.asean.org

Baldwin, R. (1989). The Growth effects of 1992.Economic Policy, 9, 247-281.

Baldwin, R. (1997). Review of Theoretical Developments on Regional Integration. Regional Integration and 
trade liberalization in Sub Saharan Africa, Volume I: Frame work, Issues and Methodological Perspectives. Nairobi: AERC publication.

Baldwin, R., \& Venables, A. (1995). Regional Economic Integration. In Grossman, G., Rogoff, K. (eds.), Handbook of International Economics. Amsterdam: North Holland.

Barro, R. J. (1999). Determinants of Economic Growth: Implications of the Global Evidence for Chile. Cuadernos de Economia (Latin American Journal of Economics), 36(107), 443-478.

Barro, R., \& Sala-i-Martin, X. (1995). Economic Growth. New York: McGraw-Hill.

Bassanini, A., \& Scarpetta, S. (2001). The Driving Forces of Economic Growth: Panel Data Evidence for the OECD Countries. OECD Economic Studies, 2(33), 9-56.

Berthelon, M. (2004). Growth Effects Of Regional Integration Agreements. Working Paper 278. Santiago: Central Bank of Chile.

Brunetti, A., Kisunko, G., \& Weder, B. (1998). Credibility of Rules and Economic Growth: Evidence from a Worldwide Survey of the Private Sector. The World Bank Economic Review, 12(3), 353-384.

Cameron, F. (2010). The European Union as a Model for Regional Integration. Working Paper September 2010. New York: International Institutions and Global Governance Program, Council on Foreign Relations.

Carbaugh, R. J. (2004). International Economics (9th ed.). Australia: South-western.

Caribbean Community Secretariat. (2014). The Official Website of Caribbean Community Secretariat. Retrieved from http://www.caricom.org/

Central American Integration System. (2014). The Official Website of Central American Integration System. Retrieved from http://www.sica.int/index_en.aspx

Central European Free Trade Agreement. (2014). The Official Website of Eurasian Economic Community. Retrieved from http://www.cefta.int/

Clausing, K. A. (2001). Trade Creation and Trade Diversion in the Canada-United States Free Trade Agreement. Canadian Journal of Economics, 34, 677-696.

Cline, W. R. (1978). Benefits and Costs of Economic Integration in CACM. In Cline, W. R. \& Delgado, E. (Eds.), Economic Integration in Central America. Washington: the Bookings institution.

Coe, D. T., \& Helpman, E. (1995). International R\&D Spillovers. European Economic Review, 39(5), 859-887.

Crafts, N. (2007). European Growth in the Age of Regional Economic Integration: Convergence Big Time? Background note for 2009 World Development Report, December 2007. England: University of Warwick.

De Melo, J., Montenegro, C., \& Panagariya, A. (1992). Regional Integration, Old and New. Washington DC: World Bank Policy Research Working Paper 985.

Dion, D. P. (2004). Regional integration and economic development: An empirical approach. Discussion Paper 21. Mannheim: Department of Economics, University of Mannheim

El-Agraa, A. (1994). The Economics of the European Community (4th ed.). UK: Harvester Wheatsheaf.

Eurasian Economic Community. (2014). The Official Website of Eurasian Economic Community. Retrieved from http://www.evrazes.com/en/about/

European Free Trade Association. (2014). The Official Website of European Free Trade Association. Retrieved from http://www.efta.int/

European Union. (2014). The Official Website of European Union. Retrieved from http://europa.eu/index_en.htm

Ezaki, M., \& Nguyen, T. D. (2008). Regional Economic Integration and Its Impact on Growth, Income Distribution and Poverty in East Asia: a CGE Analysis. Nagoya: Graduate School of International Development, Nagoya University.

Ezeala-Harrison, F. (1996). Economic Development: Theory and Policy Applications. Portsmouth: Greenwood Publishing Group

Fisher, S. (1993). The Role of Macroeconomic Factors in Growth. Journal of Monetary Economics, 32, 485-512.

Hanushek, E., \& Kimko, D. (2000). Schooling, Labor-Force Quality, and the Growth of Nations. American Economic Review, 90, 1184-1200.

Helpman, E. (1993). Innovation, Imitation, and Intellectual Property Rights. Econometrica, 61(6), 1247-1280. 
Henrekson, M., Torstensson, J., \& Torstensson, R. (1997). Growth Effects of European Integration. European Economic Review, 41, 1537--1557.

Hine, R. C. (1994). International Economic Integration. In Greenaway, D. \& Winters, L. A. (Eds.), Surveys in International Trade. Oxford: Blackwell.

Hoekman, B., \& Sekkat, K. (2010). Arab Economic Integration: The missing links. Working Paper April 2010. Grouped'Economie Mondiale (Sciences Po, Paris).

Khaledi, K., \& Shirazi, A. H. (2013). Estimates of Factors Affecting Economic Growth in the AgriculturalSector in the Fifth Development Plan of Iran (Emphasis on Investment). World Applied Sciences Journal, 22(10), 1492-1499.

Kibritcioglu, A. (1997). A Note on the Smithian Origins of 'New' Trade and Growth Theories. AUSBF Discussion Paper Series 7. Ankara: Ankara University.

Krieger-Boden, C., \& Soltwedel, R. (2010). European Economic Integration in Econometric Modelling-Concepts, Measures and Illustration. Kiel Working Paper 1661, November 2010. Germany: Kiel Institute for the World Economy,

Krugman, P. R. (1991). Geography and Trade. Cambridge: The MIT Press.

Kuznets, S. (1955). Economic Growth and Income Inequality. American Economic Review, 45(1), 1-28.

Lensink, W., \& Morrissey, O. (2006). Foreign Direct Investment: Flows, Volatility and the Impact on Growth. Review of International Economics, 14(3), 478-493.

Licandro, O. (2004). The Impact of Regional Integration on Economic Convergence and Growth. EUI Working Paper ECO 2004/26. Italy: Department of Economics, European University Institute.

Lichtenberg, F. (1992). R\&D Investment and International Productivity Differences. NBER Working Paper 4161. The National Bureau of Economic Research.

Lipsey, R. (1987). The Theory of Customs Unions: A General Survey. In Bhagawati, J. N. (Ed.), International Trade: Selected Readings. Cambridge: The MIT Press.

Lloyd, P. J., \& Maclaren, D. (2004) Gains and losses from Regional Trading Agreements: A survey. The Economic Record, 80(251).

Lucas, R. E. (1988). On the Mechanics of Economic Development. Journal of Monetary Economics, 22(1), 3-32.

Lyakurwa, W., McKay, A., Ng'eno, N., \& Kennes, W. (1997). RegionalIntegration in Sub-Saharan Africa: A Review of Experiences and Issues. In Oyejide, A., Elbadawi, I., \& Collie, P. (Eds.), Regional Integration and Trade Liberalization in Sub-Saharan Africa, Volume I: Framework, Issues and Methodological Perspectives. London: Macmillan.

Madani, D. H. (2001a). Regional Integration and Industrial Growth among Developing Countries: The Case of Three ASEAN Members. Washington DC: World Bank Working Paper 2697.

Madani, D. H. (2001b). South-South Regional Integration and Industrial Growth. Washington DC: World Bank Working Paper 2614.

Molle, W. (1990). The Economics of European Integration. Dartmouth Publishing Co. Ltd.

Moral-Benito, E. (2007). Determinants of Economic Growth: A Bayesian Panel Data Approach. CEMFI Working Paper 0719.Madrid: Center for Monetary and Financial Studies.

Mutharika, B. W. (1972). Towards Multinational Economic Cooperation in Africa. New York: Praeger Publishers.

Naftanow.org. (2014). About NAFTA. Retrieved from http://www.naftanow.org/

Najarzadeh, R., \& Shaghaghi, V. (2006). Regional Integration and Its Impact on Foreign Direct Investment (Case Study of the member Countries of MENA). Journal of Economic Research, 72, 337-362.

Narendra \& Goel, A. (2014). Impact of Regional Economic Integration on Economic Growth - A Review of Literature. Tactful Management Research Journal, 2(4), 1-10.

Naveh, M. H., Torosyan, T., \& Jalaee, S. A. (2012). Regional Economic Integration and its Effects on Economic Growth and Economic Welfare. World Applied Sciences Journal, 17(10), 1349-1355.

Ndambiri, H. K., Ritho, C., Ng'ang'a, S. I., Kubowon, P. C., Mairura, F. C., Nyangweso, P. M., Muiruri, E. M. \& 
Cherotwo, F. H. (2012). Determinants of Economic Growth in Sub-Saharan Africa: A Panel Data Approach. International Journal of Economics and Management Sciences, 2(2), 18-24.

Negasi, M. Y. (2009). Trade Effects of Regional Economic Integration in Africa: The Case of SADC. Pretoria: Services Sector Development and Impact on Poverty Thematic Working Group. Trade and Industrial Policy Strategies.

Owen, R. F. (2013). Governance and Economic Integration: Stakes for Asia. ADBI Working Paper Series 425.Tokyo: Asian Development Bank Institute.

Pacific Island Forum Secretariat. (2014). The Official Website of Pacific Island Forum Secretariat. Retrieved from http://www.forumsec.org/

Pelkmans, J. (2006). European Integration: Methods and Economic Analysis. UK: Financial Times Prentice Hall.

Puga, D., \& Venables, A. (1998). Trading Arrangements and Industrial Development. The World Bank Economic Review, 12, 251-270.

Quah, D. (1997). Increasingly Weightless Economies. Bank of England Quarterly Bulletin, 37(1), 49-56.

Rai, D. K. (2010). Asian Economic Integration and Cooperation: Challenges and Ways Forward for Pan-Asian Regionalism. GIGA WP 152/2010, Germany: GIGA German Institute of Global and Area Studies.

Robson, P. (1987). The Economics of International Integration. London: Allen and Unwin.

Rodrik, D. (2000). Institutions for High-quality Growth: What they are and How to Acquire them. Studies in Comparative International Development, 35, 3-31.

Romer, P. M. (1986). Increasing Returns and Long-Run Growth. Journal of Political Economy, 94(5), 1003-1037.

Salvatore, D. (2007). International Economics (9th ed.). Hoboken: John Wiley and Sons.

Snorrason, S. T. (2012). The Theory of Trade Agreements, Economic Integration, Size of Economies, Trade Costs and Welfare. In: Asymmetric Economic Integration, Size Characteristics of Economies, Trade Costs and Welfare, Contributions to Economics, Springer-Verlag Berlin Heidelberg.

Solow, R. M. (1956). A Contribution to the Theory of Economic Growth. Quarterly Journal of Economics, 70(1), 65-94.

Sousa, J., Thierry, M., \& Soledad, Z. (2011). Market Access in Global and Regional Trade. Conference at the IVth Regional Integration Network (LACEACERES, Monte Video).

South Asian Association for Regional Cooperation. (2014). The Official Website of South Asian Association for Regional Cooperation. Retrieved from http://saarc-sec.org

Summers, R., \& Heston, A. (1991). The Penn World Table (Mark 5): An Expanded Set of International Comparisons, 1950-1988. Quarterly Journal of Economics, 106(2), 327-368.

Tolo, W. B. J. (2011). The Determinants of Economic Growth in the Philippines: A New Look. IMF working paper WP/11/288. Washington DC: Asia and Pacific Department, International Monetary Fund.

Union of South American Nations. (2014). The Official Website of Union of South American Nations. Retrieved from http://www.unasursg.org/

Vamvakidis, A. (1998). Regional Integration and Economic Growth? The World Bank Economic Review, 12, 251-270.

Vamvakidis, A. (1999). Regional Trade Agreements or Broad Liberalization: Which Path Leads to Faster Growth? IMF Staff Papers, 46, 42-68.

Velde, D. W. (2011). Regional Integration, Growth and Convergence. Journal of Economic Integration, 26 (1), pp. $1-28$.

Venables, A. (1999). Regional Integration Agreements: a Force for Convergence or Divergence? Washington DC: World Bank Working Paper 2260.

Walz, U. (1995). Trade Liberalization, Factor Mobility, and Regional Growth. Journal of Institutional and Theoretical Economics, 151, 505-525.

Walz, U. (1997a). Growth and Deeper Integration in a Three-Country Model. Review of International Economics, 
$5,492-507$.

Walz, U. (1997b). Dynamic Effects of Economic Integration: A Survey. Open Economies Review, 8, 309-326.

Walz, U. (1999). Dynamics of Regional Integration. Physica-Verlag, Heilderberg.

Winters, L. A. (1993). The European Community: A Case of Successful Integration. In De-Melo, J., \& Panagariya, A. (Eds.), New Dimension in Regional Integration. Cambridge: Cambridge University Press.

\section{Copyrights}

Copyright for this article is retained by the author(s), with first publication rights granted to the journal.

This is an open-access article distributed under the terms and conditions of the Creative Commons Attribution license (http://creativecommons.org/licenses/by/4.0/). 